\title{
Meandering of Tributaries of the Tigris River Due to Mass Movements within Iraq
}

\author{
Varoujan K. Sissakian', Mawahib F. Abdul Jab'bar², Nadhir Al-Ansari ${ }^{3 *}$, Sven Knutsson ${ }^{3}$ \\ ${ }^{1}$ Consultant Geologist, Erbil, Iraq \\ ${ }^{2}$ Iraq Geological Survey, Erbil, Iraq \\ ${ }^{3}$ Lulea University of Technology, Lulea, Sweden \\ Email: varoujan49@yahoo.com, mawaheb geosurv@yahoo.com, ${ }^{*}$ nadhir.alansari@ltu.se, \\ Sven.Knutsson@ltu.se
}

Received 12 August 2014; revised 4 September 2014; accepted 20 September 2014

Copyright (C) 2014 by authors and Scientific Research Publishing Inc.

This work is licensed under the Creative Commons Attribution International License (CC BY). http://creativecommons.org/licenses/by/4.0/

\section{(c) (i) Open Access}

\section{Abstract}

Tigris and Euphrates are the main rivers in Iraq. The former has 5 main tributaries while the latter has no tributaries within Iraq. All these rivers exhibit meandering and/or shifting of their courses due to many reasons; such as mass movements and alluvial fan's development. The meandering and shifting of river courses due to mass movements is dealt with in this study. Many examples are given from different parts of Iraq within different rivers and streams. In each case, the geology of the involved area is described; the reasons of the shifting and/or meandering of the river course are given. GIS technique was used to determine the coverage of the involved area. Landsat, Google Earth and DEM images were used to indicate the suffered areas from shifting and meandering of the rivers and streams. When possible, age of the shifting and/or meandering of the river and stream courses was estimated; using exposure age determination; mainly depending on the presence of river terraces, erosional forms, vegetation cover and the maturity of the involved area. Some of the given examples of shifting of river courses were found to be still active; others are inactive. In many cases, indications for very large mass movement phenomena were seen. Moreover, some of the large involved areas are highly populated, others includes few houses and/ or farms. The majority of the meanders are developed due to mass movement phenomena; others are caused by alluvial fans and/or tectonic features, lime plunging of anticlines.

\section{Keywords}

Tigris, River Meanders, Mass Movements, Alluvial Fans, Erosion, Iraq

\footnotetext{
${ }^{*}$ Corresponding author.
} 


\section{Introduction}

Iraq is part of the Middle East. It covers an area of 433,970 square kilometers populated by about 32 million inhabitants (Figure 1 and Figure 2) [1] [2]. Iraq is well known by its two main rivers the Tigris and Euphrates, the former has five main tributaries; called Fiesh Khabur, Gretaer Zab, Lesser Zab, Adhaim and Diyala (Sirwan), in addition to tens of sub-tributaries [1] [3] [4]. All of them exhibit acute meanders along their courses. Some of the meanders are formed due to tectonic influence, when the course follows a plunge of an anticline; others are formed due to mass movement phenomena. The braided river system, however, also forms meanders, but are not acute as those formed due to tectonic influence and/or mass movement phenomena.

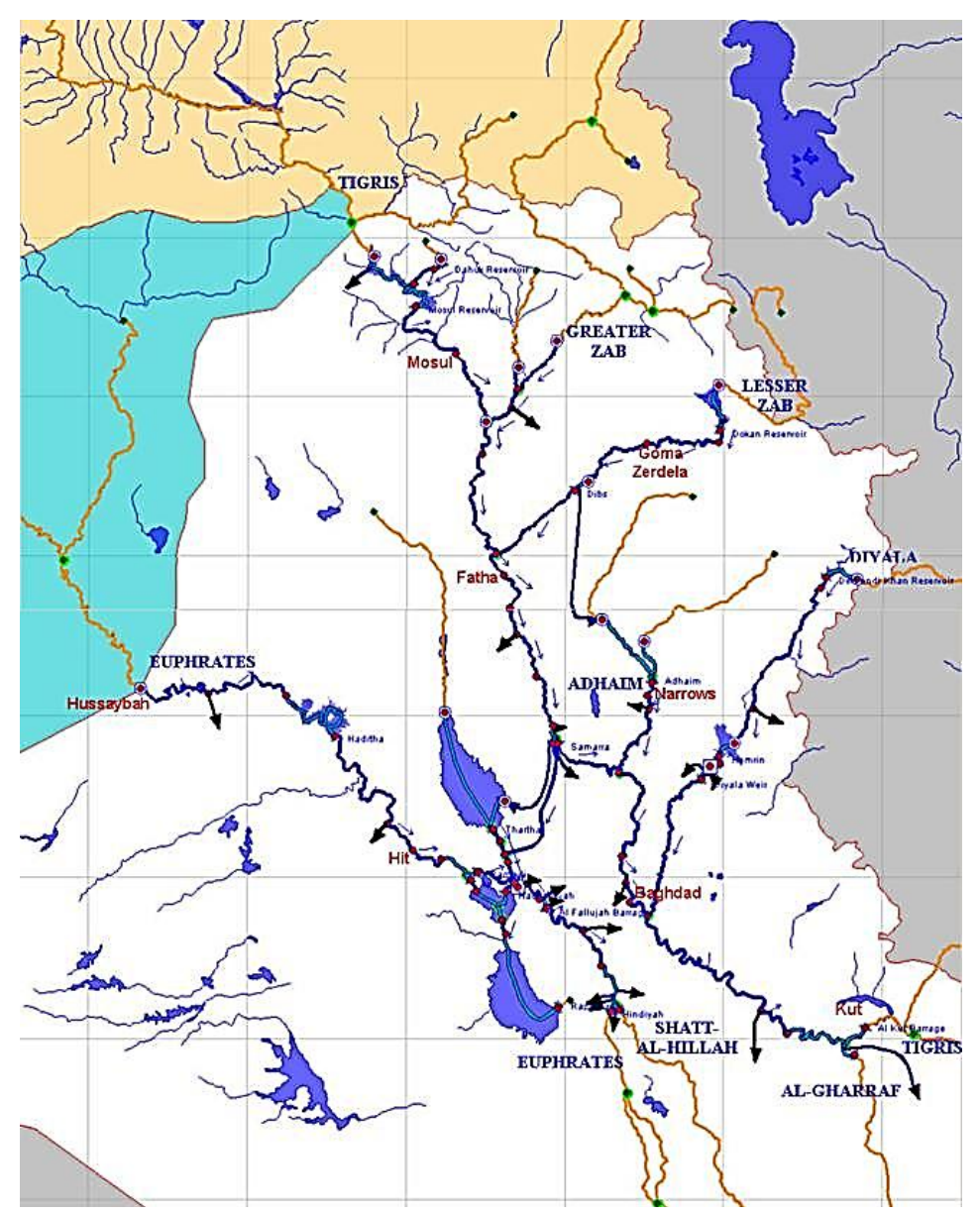

Figure 1. Main rivers and their tributaries.

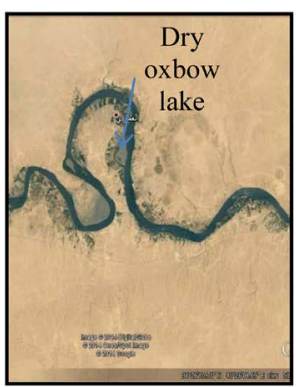

(a)

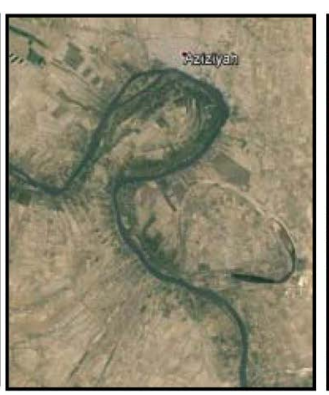

(b)

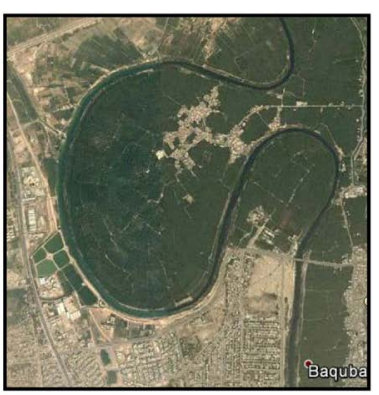

(c)

Figure 2. Google Earth images of natural meanders in mature rivers, (a) Euphrates River; (b) Tigris River; (c) Diyala River. 
Rivers usually form normal meanders along their courses, especially when they are considered as old rivers. The same river; however, can have three stages of maturity; these are: youth, mature and old during its course, but in different places [5]. This depends on the morphology and relief difference of the land through which a river is flowing. Good examples in Iraq are the Euphrates, Tigris and Diyala rivers (Figure 2), where they form a series of meanders along their courses, not related to mass movements.

The mechanism of normal meandering is explained in Figure 3, where erosion took place in the outside part of a bend and deposition in the inside part of a bend. The river may erode an acute meander during heavy floods leaving an oxbow lake, which may dry after a certain time (Figure 3). However, meanders may develop due to tectonic influence, when a river follows along a plunge of an anticline; due to alluvial fans (Figure 4); or the course is shifted due to a mass movement, where the course turns round the moved mass. The latter case is the objective of the current study.

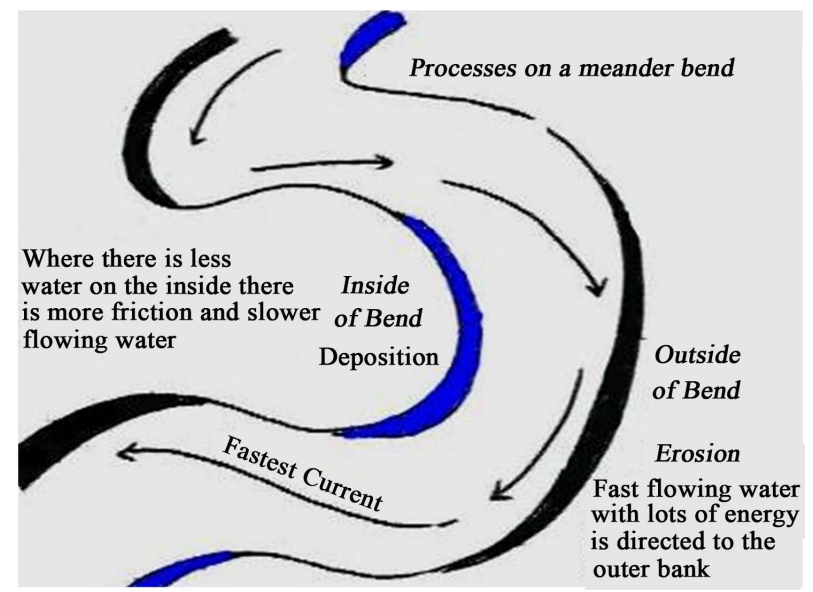

(a)

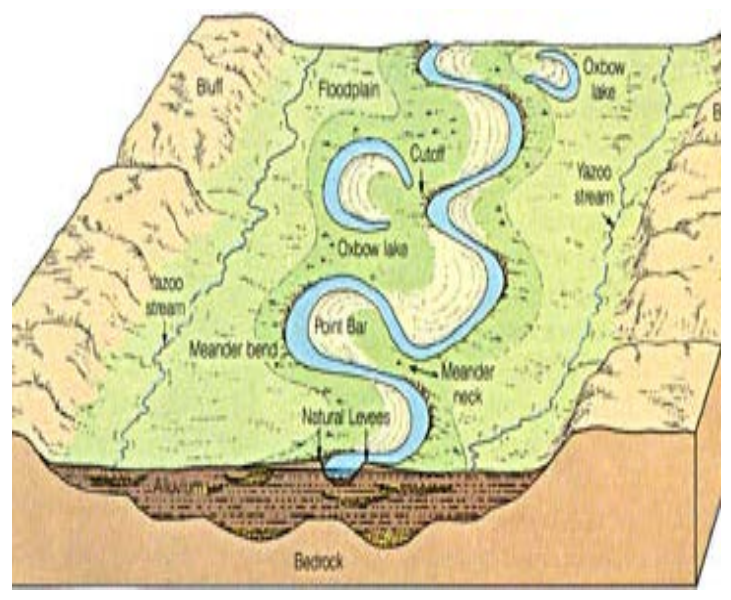

(b)

Figure 3. Meander formation. (a) Process on a meander bend; (b) Map view (Internet data).

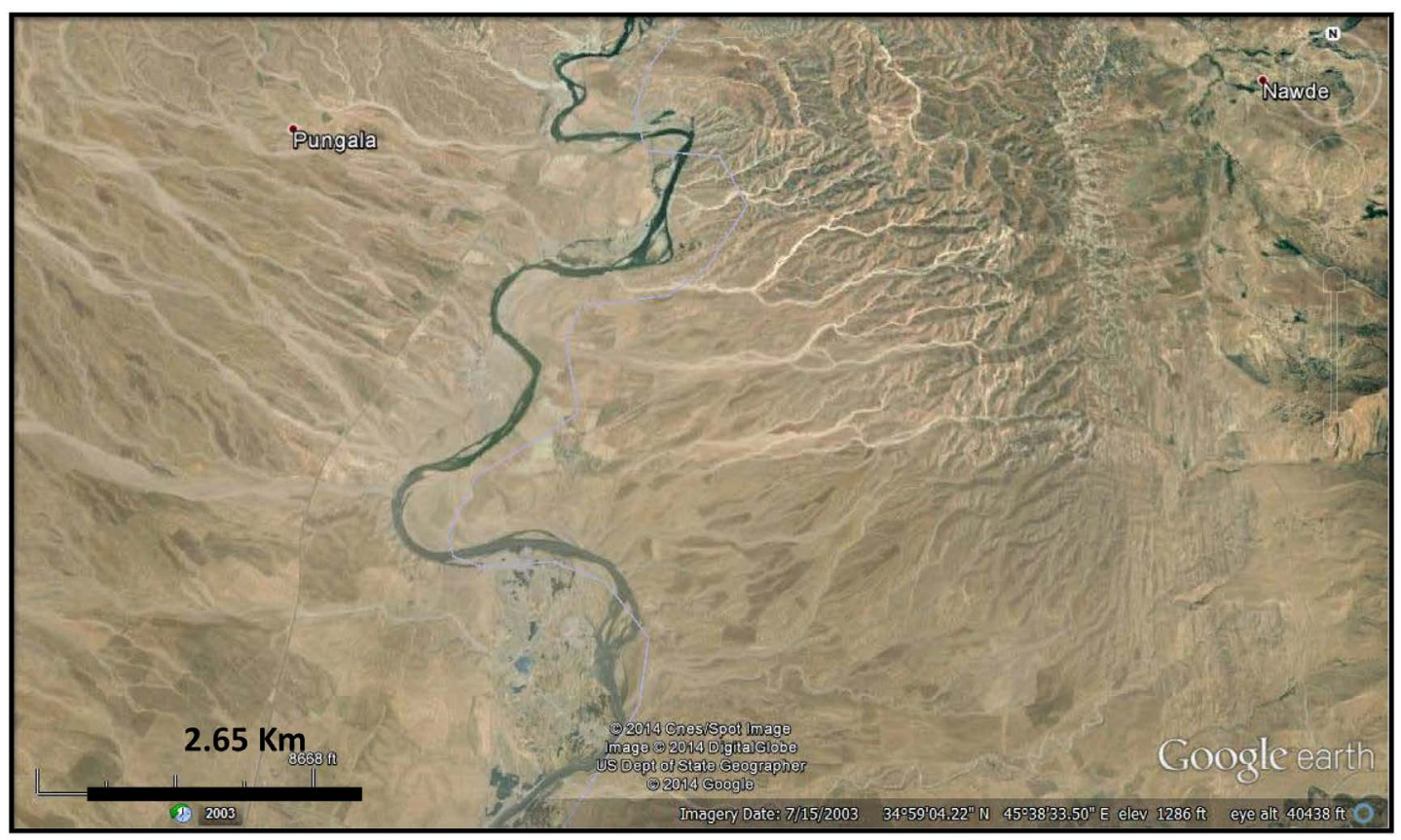

Figure 4. Google Earth image of a series of meanders along the Diyala River, south of Derbendi Khan town. The meanders are developed due to alluvial fans of many large valleys that drain both side slopes, which are built-up of clastics and conglomerate. 
Mass movements have different terminology in different literatures; they include four main types (Figure 5): Slide, fall, creep and flow [6] [7]. In Iraq, the main types of mass movements are: Flow and slide [8] [9]. The active mass movements, in Iraq are in the north and northeast, with decreasing frequency towards the central part, where they totally diminish within the Mesopotamia Plain, due to type of the sediments and low relief. One of the main reasons for triggering mass movements is the change in pore water pressure [10] [11].

Mass wasting, also known as slope movement or mass movement, is the geomorphic process by which soil, sand, regolith, and rock move downslope typically as a mass, largely under the force of gravity, but frequently affected by water and water content as in submarine environments and mudslides. Types of mass wasting includes creeps, slides, flows, topples, and falls, each with its own characteristic features, and taking place over timescales from seconds to years [12].

No direct specialized work was carried out in Iraq concerning meandering of rivers due to mass movement. However, very few articles were published concerning mass movements in different parts of Iraq, among them are:

-Sissakian [8] reported about different types of mass movements in Iraq and concluded that the most common types are mud flow, toppling and landslide.

-Sissakian [9] reported about the types of mass movements in Iraq with many examples and their geological hazards affect.

-Sissakian and Fouad [13] reported about the morphotectonics of the Tigris River in the central part of Iraq and concluded that many meanders in the river were due to landslides.

-Karim et al. [14] studied a large landslide in Pera Magroon Mountain, north Iraq and deduced the reasons and movement rate of the landslide.

-Sissakian et al. [15] studied the existing landslides in Khanooga area, central part of Iraq, along the Tigris River and concluded that part of the meandering of the river was related to a landslide.

-Sissakian et al. [16] studied the influence of the mass movements on Makhoul dam; located on the Tigris River and concluded that the existing landslides will affect the stability of the dam after impounding of its reservoir.

-Sissakian and Abdul Jab'bar [17] studied the transversal streams in northern parts of Iraq and concluded that the courses of some streams were related to landslides.

-Hamsur [18] studied the influence of the mass movements on the stability of the proposed Bassara Dam, norht Iraq.
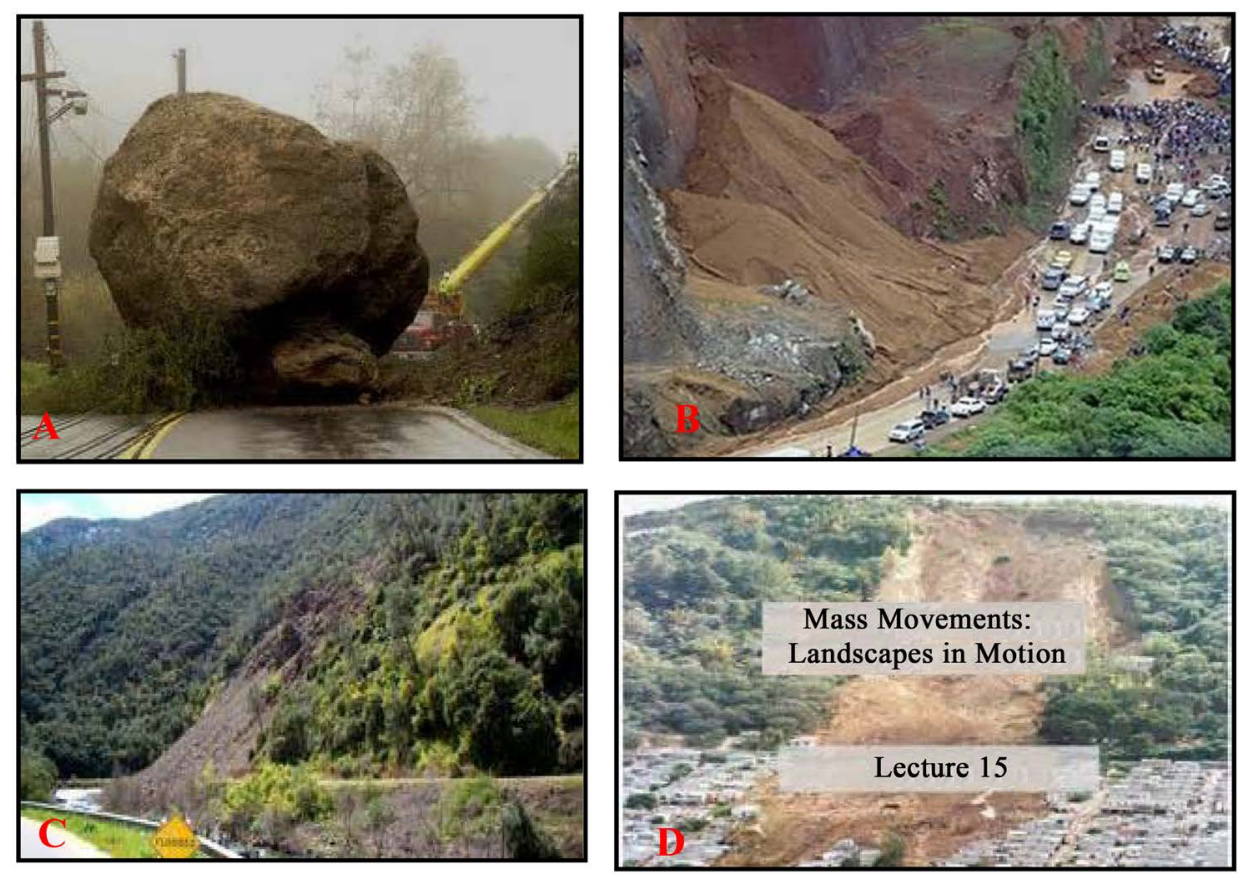

Figure 5. Four types of mass movements (after [19]) A) Fall; B) Flow; C) Slide; and D) creep. 
Meandering can form an obstacle for any engineering work or hydrological study unless the reason for meandering is revealed, especially when it is still active. The aim of this study is to investigate some of the main acute meanders along the Tigris River and some of its main tributaries in different parts Iraq (Figure 1 and Figure 6). The reason of the existence of the meander is given and, age estimation for its development is also given, when relevant indication(s) is available.

\section{Materials and Methods}

To achieve the aim of this study, the following materials were used:

-Geological maps, at scale of 1:100,000, 1:250,000 and 1:1,000,000

-Topographical maps, at scale of 1:100,000 and 1:250,000

-Geological reports concerning this study

-Google Earth, DEM and Satellite images

-Relevant published articles and thesis

-GIS techniques and programs to indicate some numerical data concerning the involved areas.

The geological and topographical maps with the Google Earth, DEM and Satellite images were used to recognize the indications of mass movements and their effect on meandering of rivers and streams. Within GIS and Digital Elevation Model (DEM) applications, spatial analysis and hydrological tools of Arc GIS were used to calculate the involved parts in the studied area. The simplest morphological analysis involves the study of elevation data. In the present approach, DEMs were displayed for visual inspection as grey-scale images, 3D surface views, and shaded relief models or as combinations of these. Some structural data were also reviewed to elucidate the relation between surface geology and the meandering.

\section{Hydrological Characteristics of the Iraqi Rivers}

The rivers Tigris and Euphrates with their tributaries form the main surface resources in Iraq. Details of these basins can be found in [1]-[3]. The catchments area of these rivers is shared by five countries: Iraq, Turkey, Iran, Syria and Saudi Arabia (Figure 1 and Figure 6).

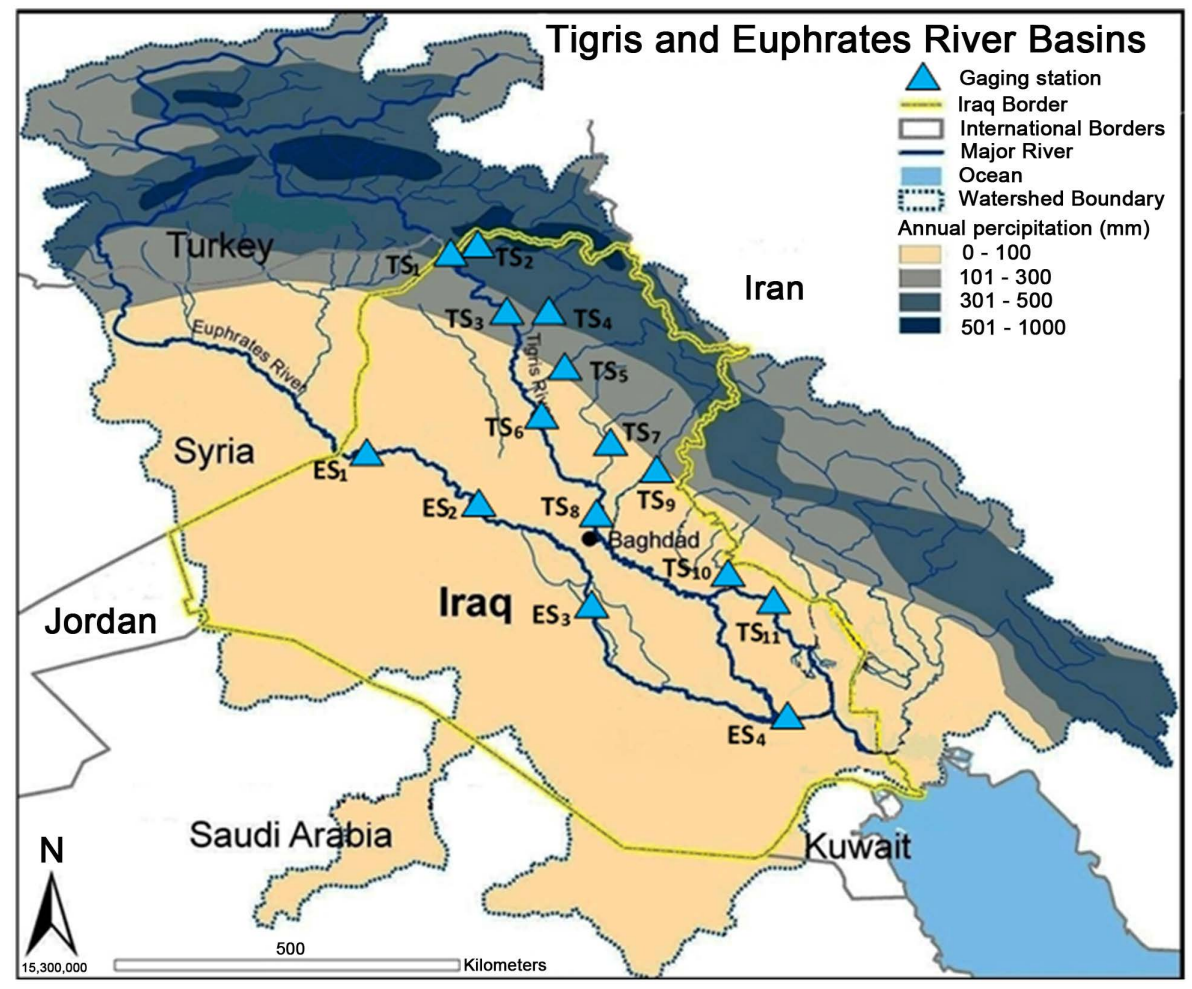

Figure 6. Catchments area of rivers tigris and euphrates. 
The River Tigris rises in the southeastern part of Turkey on the southern slopes of the Touros mountain range and drains an area of 472,606 $\mathrm{km}^{2}$ which is shared by Turkey, Syria and Iraq. Its total length is about $1800 \mathrm{~km}$ (Figure 1 and Table 1). About 58\% of the basin lies in Iraq. Three major tributaries (Butman Su, Karzan and Razuk) join the Tigris before it reaches the Turkish/Iraqi border. The mean annual flow of the river does not exceed $64 \mathrm{~m}^{3} / \mathrm{S}$ and it increases at Razuk to $413 \mathrm{~m}^{3} / \mathrm{S}$. It enters Iraq at Fiesh Khabur where the Khabur tributary joins the main river at a small distance to the south. The mean annual flow of the Khabur is $68 \mathrm{~m}^{3} / \mathrm{S}$. It is 181 $\mathrm{km}$ long and drains an area of $6143 \mathrm{~km}^{2}$. The River Tigris flows towards the south and reaches the first major city (Mosul). Its mean discharge at Mosul reaches $630 \mathrm{~m}^{3} / \mathrm{S}$.

The Greater Zab River joins the Tigris about $60 \mathrm{~km}$ south of Mosul. The confluence of the two rivers is situated midway between Mosul and Sharkat cities. This tributary drains an area of 25,810 $\mathrm{km}^{2}$ of which about $62 \%$ lies in Iraq. This tributary is one of the largest with a mean annual flow of $418 \mathrm{~m}^{3} / \mathrm{S}$ and it is $462 \mathrm{~km}$ long.

Further south, the Lesser Zab tributary joins the Tigris at Fatha. This tributary is $302 \mathrm{~km}$ long and drains an area of $21,476 \mathrm{~km}^{2}$ (75\% in Iraq) with a mean annual flow of $227 \mathrm{~m}^{3} / \mathrm{S}$ whiles the mean annual flow of the Tigris reaches $1340 \mathrm{~m}^{3} / \mathrm{S}$ downstream of this confluence. South of Fatha, the Adhaim tributary joins the Tigris. This tributary is $330 \mathrm{~km}$ long and drains an area of 13,000 $\mathrm{km}^{2}$ which lies totally in Iraq [20]. The mean annual flow of this river reaches $25.5 \mathrm{~m}^{3} / \mathrm{S}$. This tributary runs dry between June and November each year. Further to the south, the last major tributary, the Diyala River joins the Tigris south of Baghdad. The Diyala basin is $31,846 \mathrm{~km}^{2}$ of which about $20 \%$ lie in Iran. The mean daily flow of this tributary is $182 \mathrm{~m}^{3} / \mathrm{S}$ and the river is 574 $\mathrm{km}$ long.

No major tributary joins the River Tigris south of Baghdad. Few canals draw water from the Tigris in this region for irrigation purposes. For this reason, the mean annual daily flow of the river falls below its value at Baghdad $\left(1140 \mathrm{~m}^{3} / \mathrm{S}\right)$ in Kut and Amara cities at the south [21] [22].

The River Euphrates is $2786 \mathrm{~km}$ long and rises from the southeastern parts of Turkey. It drains an area of $444,000 \mathrm{~km}^{2}$ shared by four countries (Iraq 41\%, Turkey 28\%, Syria 17\% and Saudi Arabia 14\%) (Table 1). The Rivers Karah Su and Murad Su join together in the southeastern parts of Turkey at Kuban forming the River Euphrates. The River enters Syria at Jarablis where it runs $675 \mathrm{~km}$ and then enters Iraq. Thirty kilometers south of Jarablis, the Sajor tributary joins the Euphrates. Further downstream, two tributaries, the Balikh and Khabur, join the main river after which it crosses the Iraqi border at Hasaibah. The mean daily discharge of the Euphrates River inside Iraq (at Hit) is $909 \mathrm{~m}^{3} / \mathrm{S}$ [23] [24]. Inside Iraq, no tributary contributes water to the river. The river supplies a number of small canals in the central and southern parts of Iraq for irrigation purposes (Figure 1). Some of its water is diverted to the Habaniya reservoir during floods, which is situated about $40 \mathrm{~km}$ south of Ramadi. About $135 \mathrm{~km}$ south of Faluja, the Hindiya barrage diverts a maximum discharge of $471.5 \mathrm{~m}^{3} / \mathrm{s}$ to small parallel tributaries.

The Euphrates channel south of Kifil is divided into two main channels (Kufa and Shamiya), and they joins again at Mushkhab. Further downstream, the channel splits again about $25 \mathrm{~km}$ south of Shanafiya and rejoins near Simawa. Then the river enters Hamar marsh, where it forms two main channels within Hamar marsh. One of the channels (northern) joins the Tigris River at Qurna orming (known as the Shat Alarab River) while the other channel joins the Shat Alarab River at Karmat Ali.

Table 1. Characteristics of tigris and euphrates rivers (source [1] [2]).

\begin{tabular}{|c|c|c|c|c|c|}
\hline \multirow{2}{*}{ River } & \multirow{2}{*}{ Tributaries inside Iraq } & \multirow{2}{*}{ Length (km) } & \multicolumn{2}{|c|}{ Catchment area } & \multirow{2}{*}{ Flow $\left(\mathrm{m}^{3} / \mathrm{S}\right)$} \\
\hline & & & Total $\left(\mathrm{km}^{2}\right)$ & Inside Iraq (\%) & \\
\hline \multirow{6}{*}{ Tigris } & Main River & 1800 & 472,606 & 58 & 630 (Mosul) \\
\hline & Fiesh Khabur & 181 & 6143 & 43 & 68 \\
\hline & Greater Zab & 462 & 25,810 & 62 & 418 \\
\hline & Lesser Zab & 302 & 21,476 & 75 & 227 \\
\hline & Adhaim & 330 & 13,000 & 100 & 25.5 \\
\hline & Diyala & 574 & 31,846 & 80 & 182 \\
\hline Euphrates & Main River & 2786 & 444,000 & 41 & 909 (Hit) \\
\hline
\end{tabular}


It is noteworthy to mention that the Tigris and Euphrates River discharge changes with time (Figure 7). These changes are due to the global climate change and the dams constructed in Turkey and Syria. There are 8 dams on Euphrates in Turkey and Syria and 5 dams on Tigris in Turkey. The Tigris River mean discharge at Mosul city prior to 1984 was $701 \mathrm{~m}^{3} / \mathrm{S}$ and dropped to $596 \mathrm{~m}^{3} / \mathrm{S}$ afterward [1]. This implies that $15 \%$ of the river discharges were been decreased. The Euphrates River mean discharge at Hit and Haditha cities prior to 1972 was $967 \mathrm{~m}^{3} / \mathrm{S}$ and dropped to $553 \mathrm{~m}^{3} / \mathrm{S}$ after 1985 [1]. The percentage decrease in river discharge is $43 \%$.

\section{Examples of River Meandering Due to Mass Movements.}

Using different types of images, tens of meandering of rivers and streams due to mass movement phenomena were recognized in different parts of Iraq. The best representative examples were selected and presented in this study. In each case, the geology, type of the movement, coverage of the involved area, reason of triggering and if possible; the age of the mass movement phenomenon was estimated. The selected examples were classified according to the river and/or stream through which the meandering occurs, the involved areas are shown in Figure 1. Hereinafter are selective and representative examples of meanderings in different rivers; caused by mass movements.

\subsection{Tigris River}

The Tigris River, in Iraq flows in low relief mountainous areas; therefore, no large mass movements have occurred that caused shifting of the river's course. However, few meandering due to mass movements occur along the river's course.
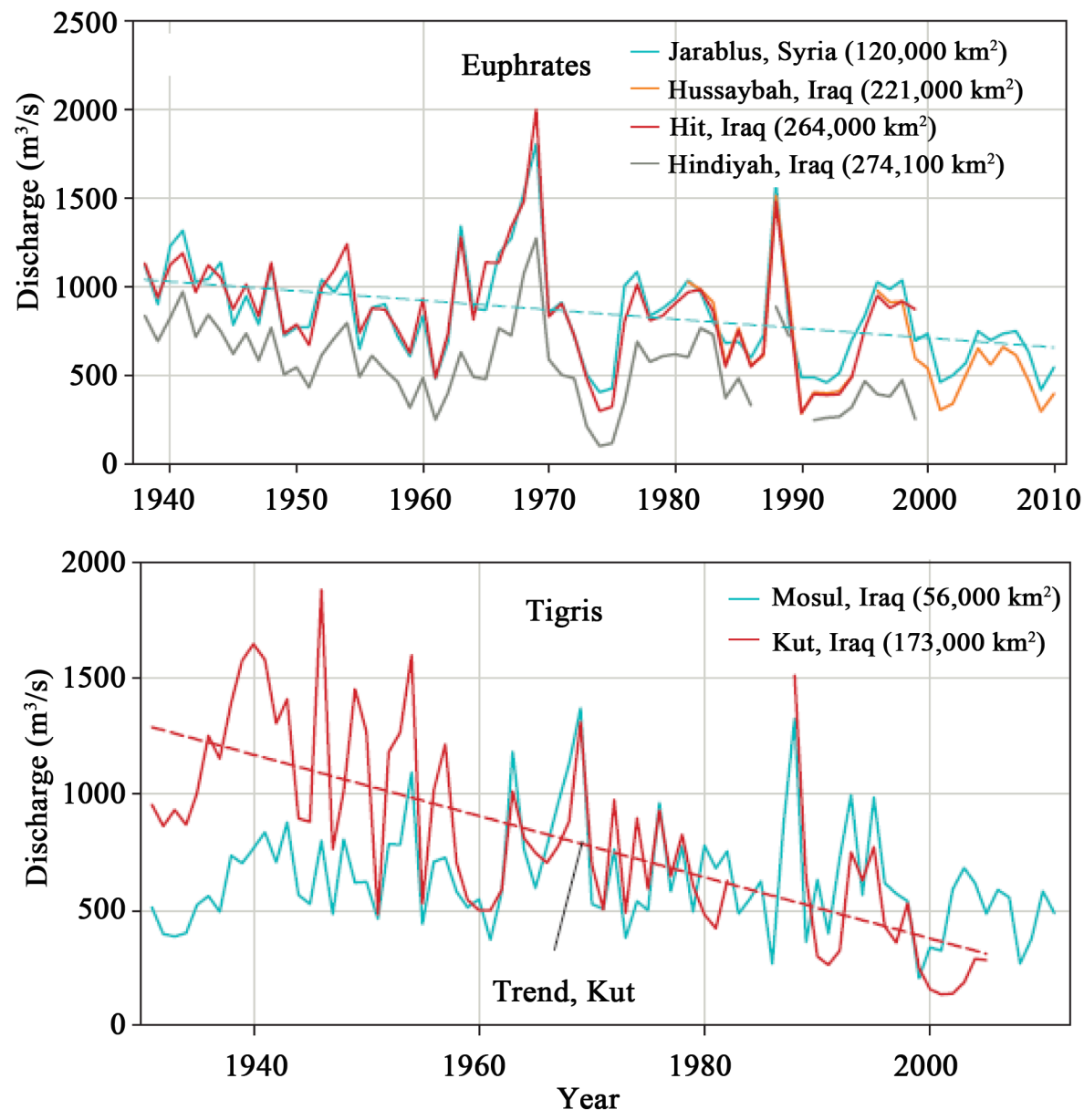

Figure 7. Mean annual discharge of rivers tigris and euphrates [2]. 
Figure 8 shows two meanders caused by mud flows along the course of the Tigris River. The involved areas are built up of the Fatha Formation (Middle Miocene) [13]; it consists of cyclic nature of rocks, each cycle consists of green marl, limestone and gypsum. These three rocks of different mechanical characters are highly susceptible for different types of mass movements, especially after being highly saturated during heavy rain showers, besides the undercut erosion of the Tigris River. The involved area represents the southeastern plunge of Mashoora Dagh anticline [25]. The traces of the mud flow are still present in the enlarged part of (Figure 8). The river, originally was meandering around the plunge ( $\mathrm{M}$ in Figure 8), with vast flood plain (FP in Figure 8), after a mud flow the first meander was developed (No. 1 in Figure 8), then a second mud flow had occurred (No. 2 in Figure 8), which had shifted the first meander, as indicated by its strange asymmetrical meander and bulging opposite to the course of the river. After that the river had eroded and deposited its flood sediments along the meanders, consequently, modeling and modifying the easiest path, which is still in action and can be seen in the last meander bellow the water of the Mosul Dam reservoir (Figure 8). The age of the mud flow is very old since no traces of the old river course can be seen, apart from the cliffs (C in Figure 8), which indicate the original course of the river, and the large formed flood plains, especially in meander No. 1 . The coverage area of the involved area is about $2.24 \mathrm{Km}^{2}$.

\subsection{Greater Zab River}

The Greater Zab River is one of the main tributaries of the Tigris River (Figure 1); it flows within very rugged topography with high relief difference, which enables the development of different types of mass movements. Figure 9 shows many meanders along the course of the Greater Zab River, all of them are formed due to landslides. Originally, the course of the river was almost a straight line (A, B, C and D, Figure 9) flowing parallel to the axis of a syncline between Shireen and Gara anticlines, the trough of the syncline is capped by Tanjero and Shiranish formations [26]-[28]. The landslides and mud flows happened in the Shiranish and Tanjero formations, the river course was shifted in two locations; southwest wards. The trace of the ancient river course is still present in many localities (Figure 10). The age of the mass movements is very old, because the crown areas of the movements are vanished, moreover, the facing parts of the river suffer from active erosion indicating activity of the movements. The coverage area of the first part (B) is $1.258 \mathrm{Km}^{2}$ whereas that of the second part (C) is $0.982 \mathrm{Km}^{2}$.

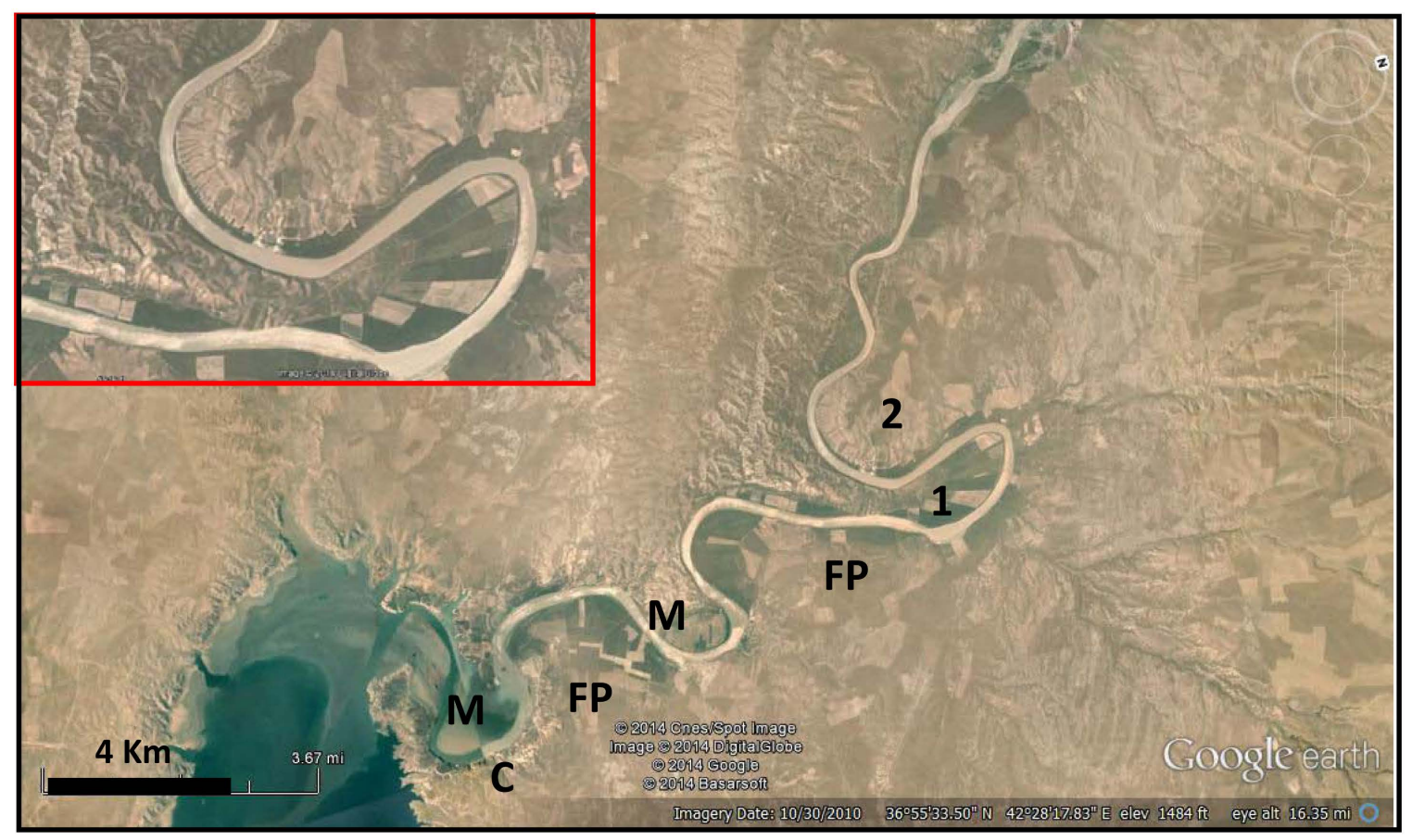

Figure 8. Google earth image (facing ne) of three acute meanders along the tigris river. 


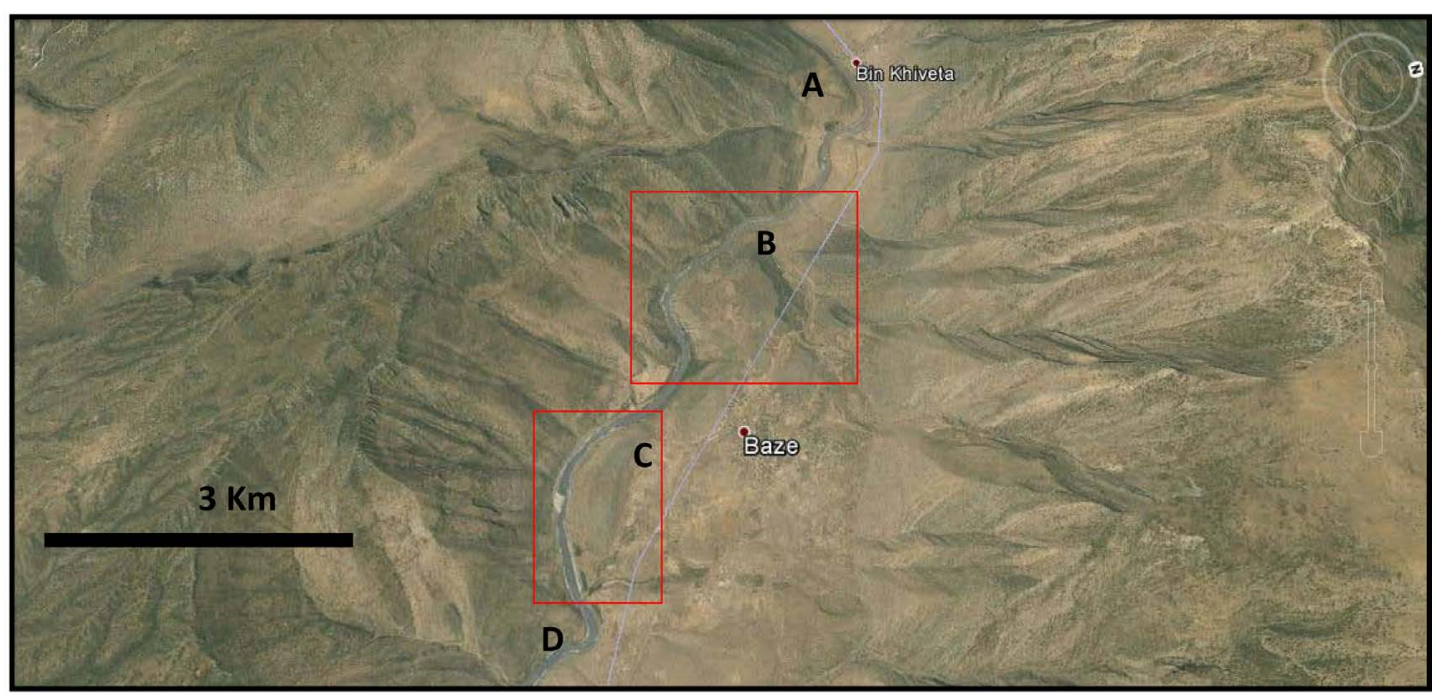

Figure 9. Google Earth image facing NE, of the Greater Zab River, with two captions. Note the original alignment of the river ((A), (B), (C) and (D)).
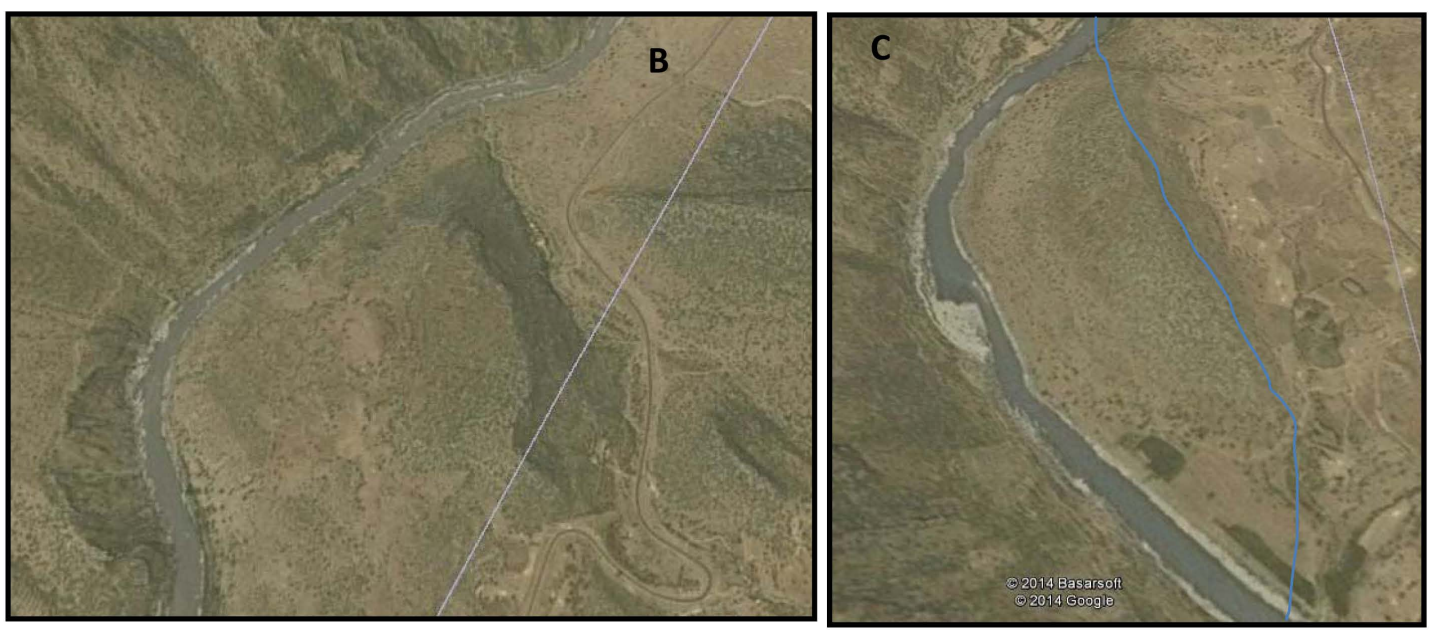

Figure 10. Google Earth images facing NE. Left: Caption B and Right: Caption C. Note the trace of the ancient river course (in blue) and traces of active erosion along the cliffs on the facing side of the river.

Figure 11 shows example of a meander within the Greater Zab River shifted by a mass movement. Originally, the river was meandering normally west of Bele town. The exposed rocks belong to the Tanjero and Shiranish formations [27]. The former consists of fine clastics with some coarse conglomerate, whereas the latter consists of bedded limestone overlain by marl. The meandering was modified by a landslide (Figure 11), the inner limit in the caption), which was shifted the river course NE wards. The age of the landslide might be few hundred years, since the crown area is still visible, beside the old course of the river, along the meandering. The coverage area of the involved part is about $0.777 \mathrm{Km}^{2}$.

\subsection{Lesser Zab River}

The Lesser Zab River is the second main tributary of the Tigris River (Figure 1). Figure 12 shows a complex meandering style of the river, which flows; in this part within the Fatha Formation [26] [28]. The Fatha Formation consists of marl, limestone and gypsum in cyclic nature. This combination of three components with different mechanical characteristics leads to favorable condition for mass movements.

Figure 12 shows the original main meander of the Lesser Zab River around the northwestern plunge of Maila anticline. The first landslide (No. 1 in Figure 12) had happened in the northeastern limb of Maila anticline caus- 


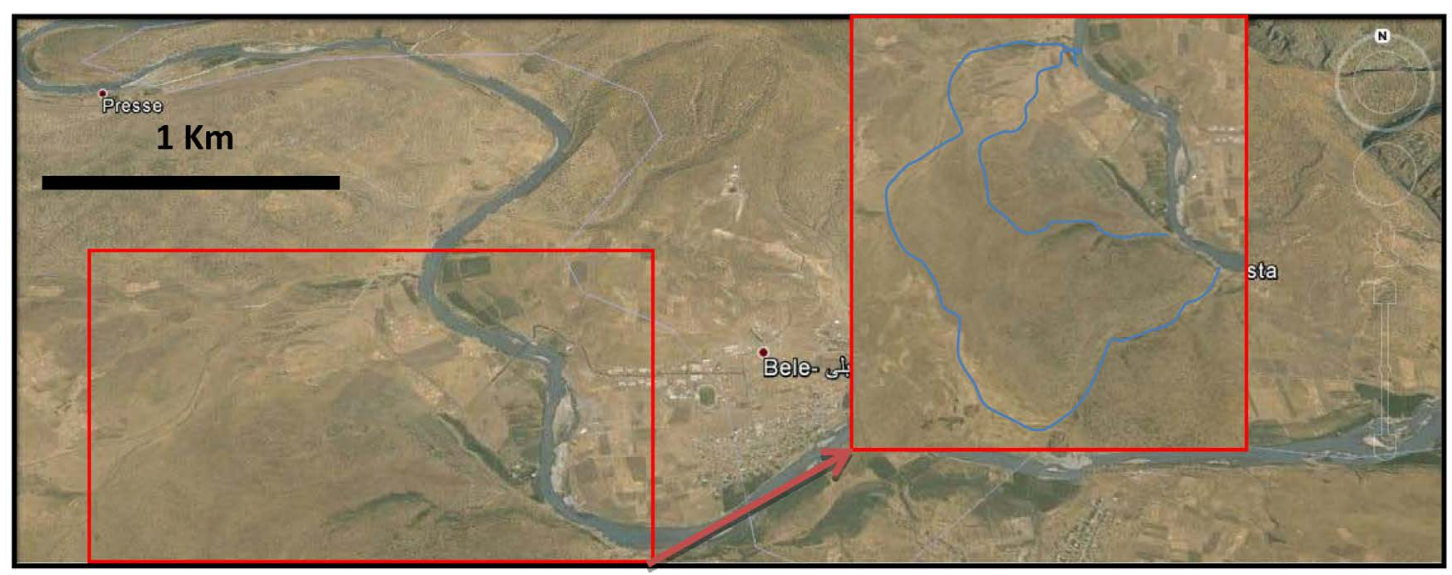

Figure 11. Google Earth image of the Greater Zab River. Note the limits of the landslide (the blue inner line) that has shifted the river course NE wards. Another large one (the bluer outer line) will be triggered when the conditions are favorable.

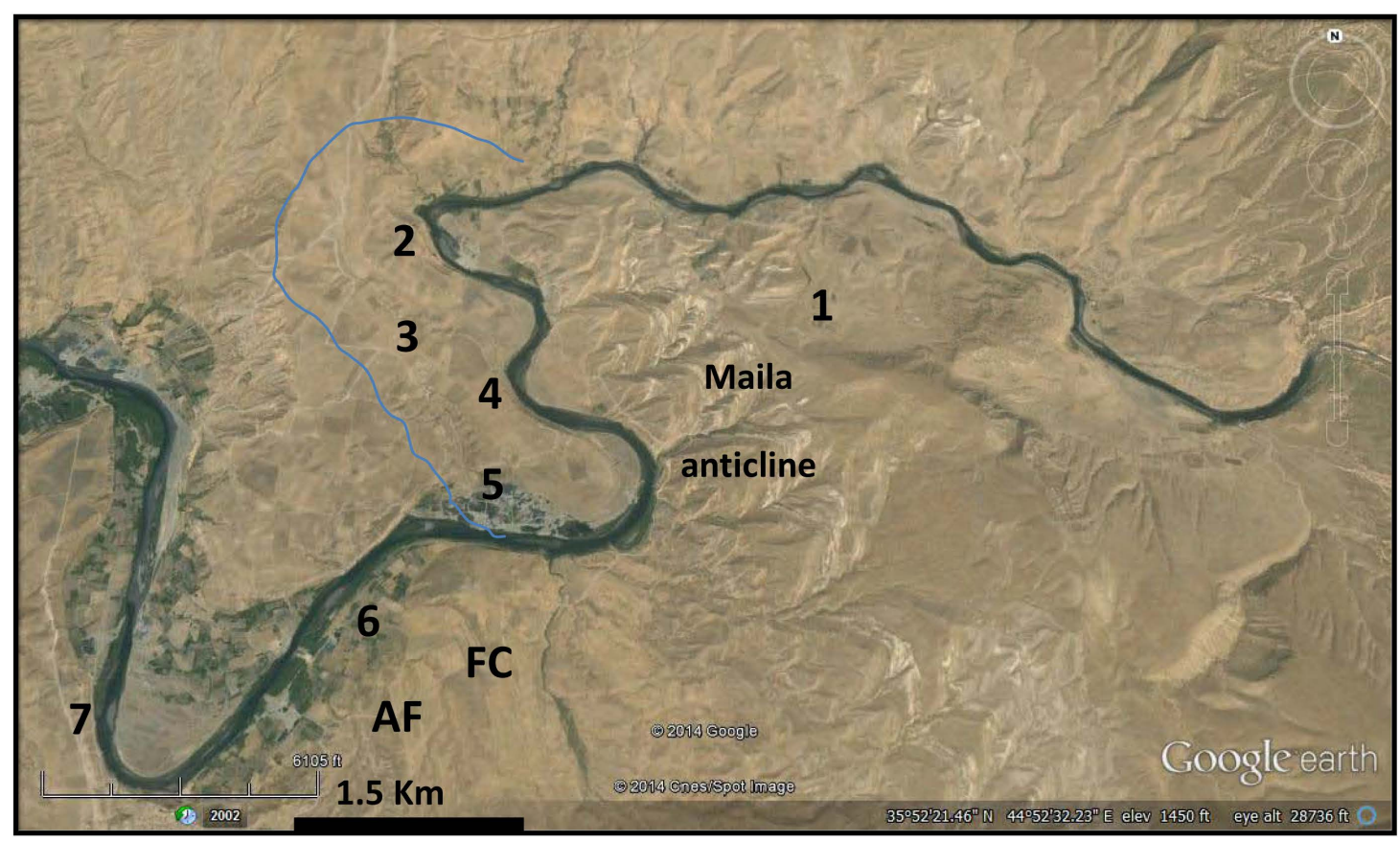

Figure 12. Google Earth image of the Lesser Zab River showing complex meandering. The blue line is the limits of the original meander of the river.

ing shifting of the river northeast wards. The trace of the crown area is still present and the continuation of the northeastern limb is concealed beneath the slid mass, as it is clear by disappearance of the flat irons within limestone beds. The trace of the original meander around the plunge is still clear, west of point 2 and marked by the blue line (Figure 12). The river; however, was shifted towards the present days course due to active alluvial fans originated from the flowing valleys towards the river. Meanders No. 2 (Figure 12) was developed due to a mud flow directly from the northwestern plunge of Maila anticline, shifting the river westwards; towards its original course. Meanders No. 3, 5 and 7 (Figure 12) were developed also by mud flows from the northeastern limb of another anticline called Cham Chamal North anticline [25]. Meander No. 4 was formed by a mud flow from the southwestern limb of Maila anticline within the flood plain of the river. Whereas meander No. 6 was developed due to large alluvial fan (AF in Figure 12), the main feeder channel (FC in Figure 12) was shifted eastwards. 
The landslide that had caused meander No. 1 is very old, most probably late Holocene, since the river terraces of Pleistocene age, which are developed along the river course; are covered by the landslide (Figure 13). The other mass movements, which had caused the other meanders (Figure 12) are few hundred years old. The coverage areas of the six meanders (No. 1, 2, 3, 4, 5, and 6) are (11.25, 1.482, 1.525, 1.32, 3.24, 2.745 and 6.615) $\mathrm{Km}^{2}$, respectively.

\subsection{Diyala River}

The Diyala (Sirwan) River is the third tributary of the Tigris River (Figure 1), it inters Iraqi territory in the northeastern borders with Iran, east of Halabja town, and there it flows in a mountainous area with rugged topography; in the Imbricate and High Folded Zones. After that it flows in undulatory plains until it merges with the Tigris River; southeast of Baghdad (Figure 1).

Figure 14 shows a tributary of the Diyala River, near the Iraqi-Iranian international borders, east of Halabja town. The area involved is occupied by well bedded limestone, marl and fine clastics of the Shiranish Formation. Originally, the tributary was flowing northeast wards and merging with the Diyala River at point A (Figure 14). Latter, the course of the tributary was shifted southwards due to a large landslide within the Shiranish Formation to form the present day meander; in almost a straight form. It still suffers from continuous shifting due to mud flows from the already moved mass by the landslide, as indicated from the active erosional areas alongside the toe of the slid mass.
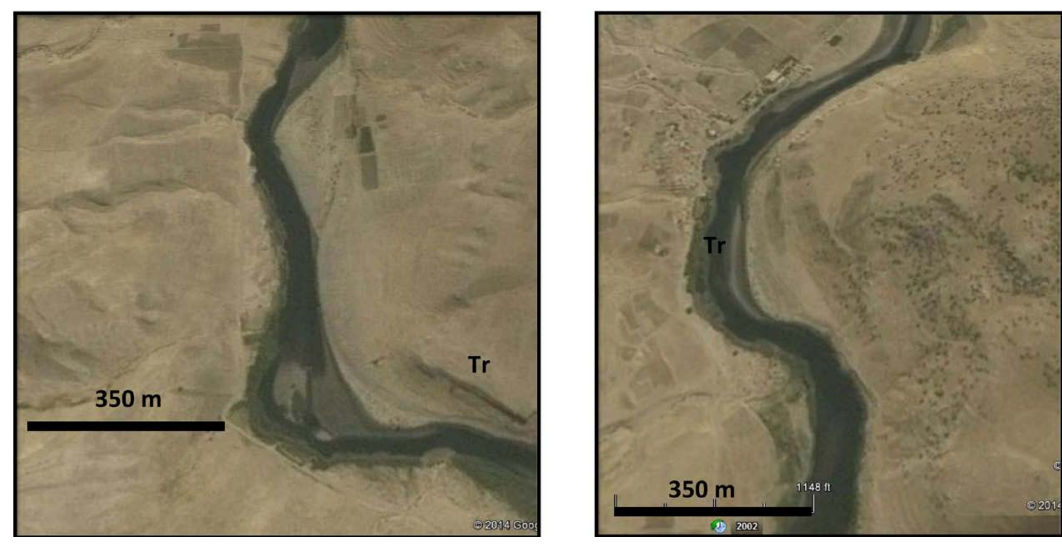

Figure 13. Enlarged Google Earth images of Figure 9 showing river terraces $(\mathrm{Tr})$ covered by landslides.

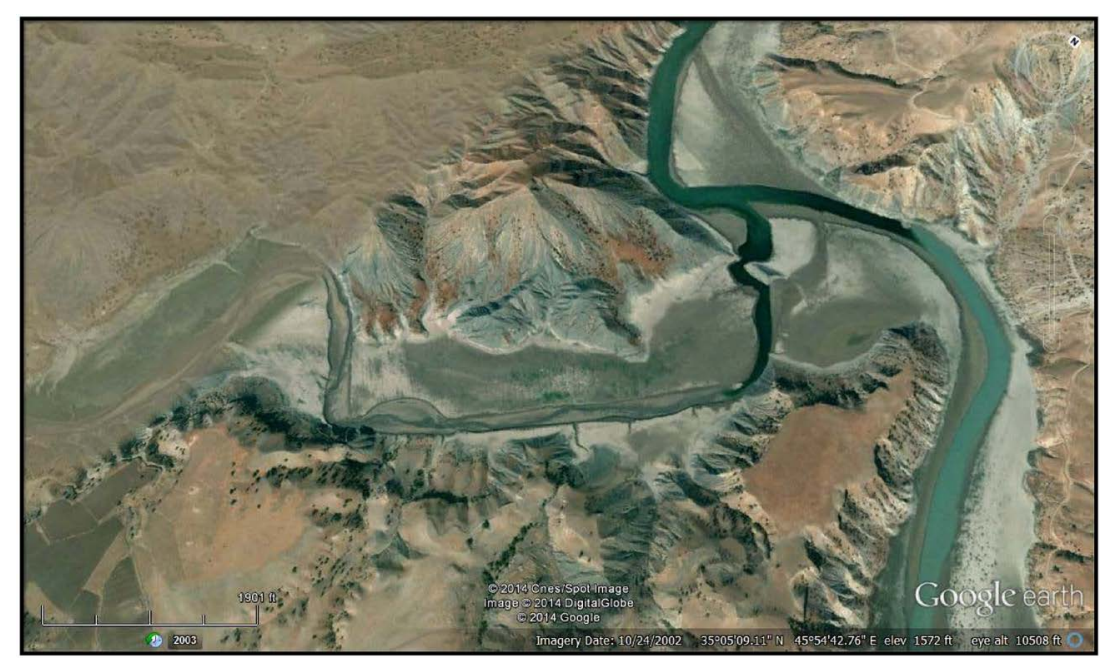

Figure14. Google Earth image, facing NE of the Diyala River (DR). Note the strange meander of its tributary due to landslide within the Shiranish Formation. 
Another meander was developed within the Diyala River; facing point A (Figure 14). This meander is developed due to mud flow (MF in Figure 13) within the marl beds of the Shiranish Formation; the ancient river course (AC in Figure 14) is still visible in the flood plain.

The age of the first meander is very old, many hundred years, since the crown area of the landslide is totally vanished, whereas the second one is recent, few ten years, since the ancient river course is still visible in the flood plain. The coverage area of the large involved areas is $1.4 \mathrm{Km}^{2}$, whereas the small one is $8000 \mathrm{~m}^{2}$.

Figure 15 shows a horse shoe meander along a tributary of the Diyala River. The meander is developed due to a landslide within the rocks of Balambo Formation [26]. The formation consists of well bedded hard limestone with intercalation of thin beds of mar, which plays a good role in triggering of mass movements. The tributary was flowing parallel to the southern limb of Halabja anticline [29]; then the course was shifted due to the landslide Figure 15). The traces of the crown vanished, but the location of the slid mass is still visible (SM in Figure 15), the presence of vegetation in the location of the slid mass with the same density of the surrounding areas indicates very old age for the slide. However, the toe area ( $T$ in Figure 15) shows bulges and crescent shapes, which indicate that the movement is still active. Figure 15 also shows many other meanders north of the described one, all are developed due to mass movements. The coverage of the involved area is $0.99 \mathrm{Km}^{2}$.

Figure 16 shows a horse shoe meander in the Diyala River, south of Derbendi Khan Dam. The area is built-up by the Fatha Formation [29]. The horse shoe meander is developed due to old and large mud flow, the area suffers now from creep; on top of which a very big mass of limestone (SM in caption B, Figure 17) is pre-

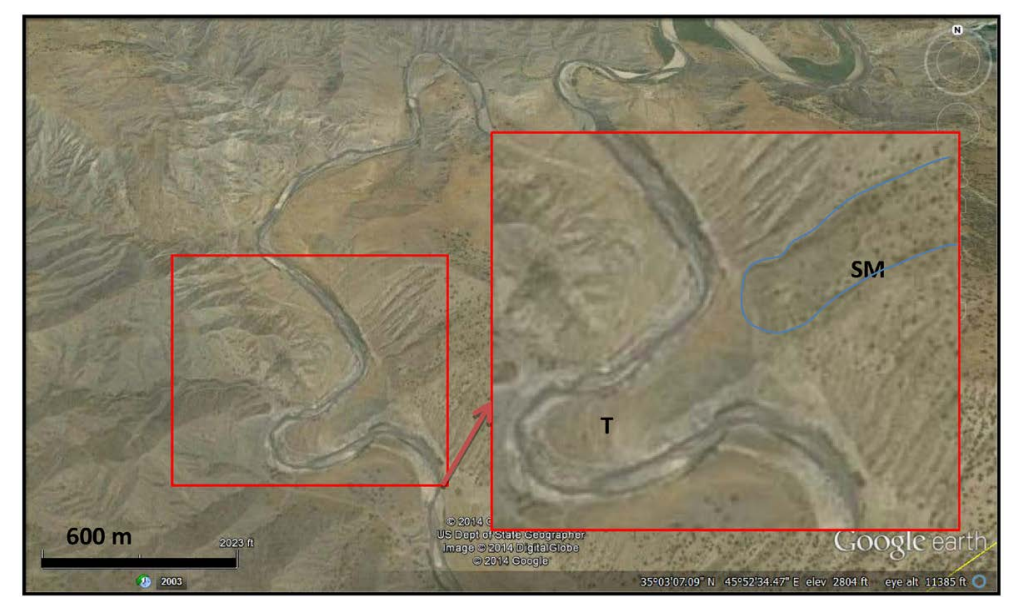

Figure 15. Google Earth image of a tributary of the Diyala River with horse shoe meander, due to landslide.

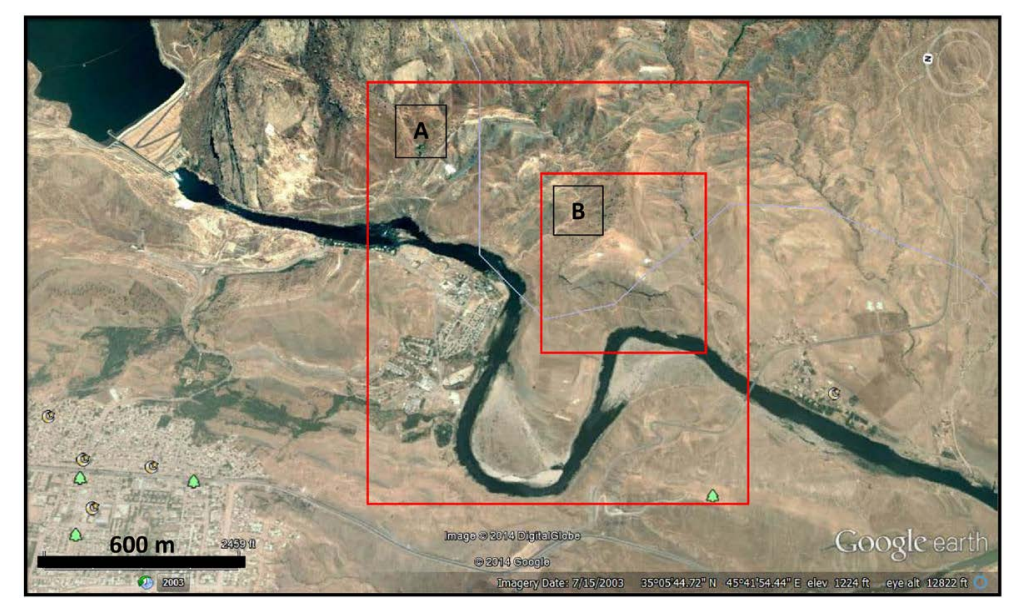

Figure16. Google Earth image of the Diyala River with horse shoe meander, due to mud flow, south of Derbendi Khan Dam. 


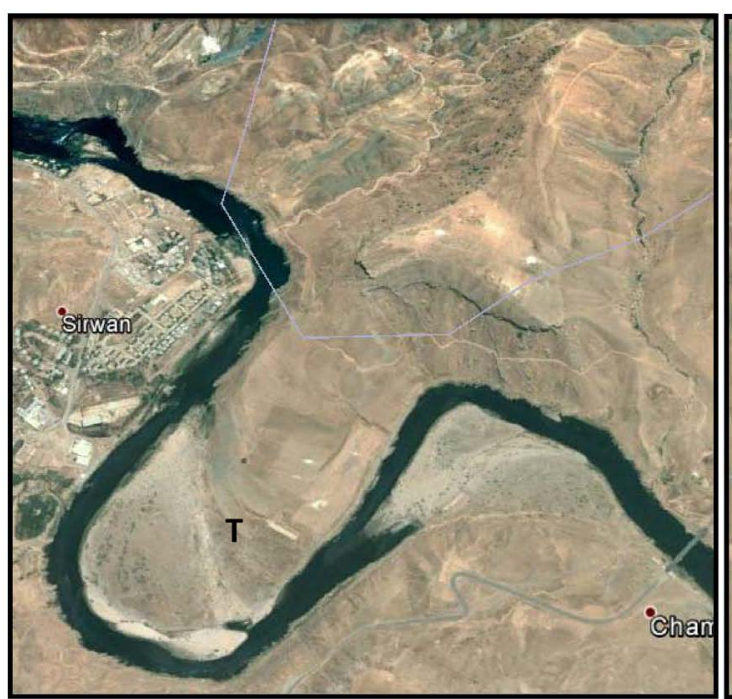

(A)

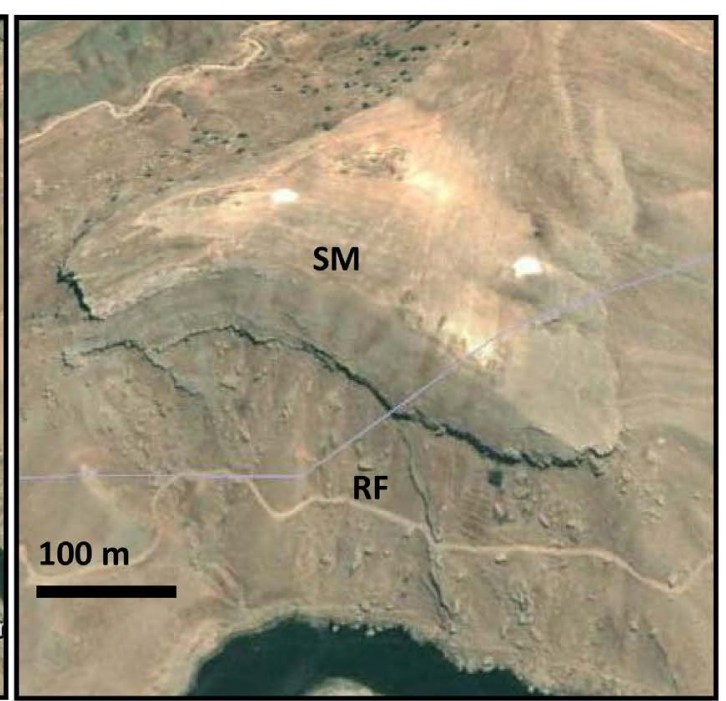

(B)

Figure 17. (A) Details of the mud flow, toe area (T); (B) Details of the slid mass (SM) and the rock fall (RF).

sent, the creep of the mud and marl is still continuous, as indicated in the toe area ( $\mathrm{T}$ in caption A, Figure 17) and the limestone mass, beside rock falls along the river course; beneath the limestone mass (RF in caption B, Figure 17).

The age of the meander is very old, many hundred or even thousand years, since the trace of the original course of the river is totally vanished, even the traces of the slid limestone mass, which is unstable. The slope is extremely dangerous and unstable. The present unpaved road; below the limestone mass will trigger and accelerate the creep and sliding of the limestone mass, which has a volume of about 3,294,000 $\mathrm{m}^{3}$. The sliding of such huge mass will certainly cause a catastrophe, especially the surrounding areas area highly populated. The already slid mass; which had shifted the river course and formed the meander, is about $0.216 \mathrm{Km}^{2}$.

\subsection{Fiesh Khabour River}

Fiesh Khabour River is one of the tributaries of the Tigris River; it inters the Iraqi territory from Turkey northeast of Zakho town. The river flows in very rugged topography with high relief differences, which enables and triggers different types of mass movements.

Figure 18 shows crossing of the Fiesh Khabour River to Matin anticline; the river exhibits many acute meanders; all of them were developed due to mass movements. A very large landslide had occurred that shifted the course of the River northwestwards. The involved area is built-up by red clastics of the Gercus Formation, overlain by well bedded limestone of the Pila Spi Formation and underlain by well bedded limestone of Khurmala Formation; the latter is underlain by black clastics of the Kolosh Formation [26]. Such succession is very favorable for triggering different types of mass movements [21].

The landslide is a complex one, it had happened in many times. The first landslide (1-2-3 in Figure 18) had shifted the river course towards NW of the present river course. The trace of the shifted river course is marked as OC in Figure 18. Latter on the river had carved its present course, which in turn was shifted by a small landslide (S in Figure 18) again northwest wards, besides another large landslide (1-6-4 in Figure 18), which also shifted the river course along its toe area. Moreover, a larger landslide (4-2-5 in Figure 18) will take place, when the sliding conditions will prevail, including the pore pressure, internal friction angle, and the loss of the retaining forces along the river course. These conditions will be fulfilled when heavy rain showers increase the water pore pressure and the river intensely erodes its left bank.

The age of the first landslide (1-2-3 in Figure 18) is very old, many hundred years or even more, although the crown area (point 2 in Figure 18) is still present. This is attributed to the soft clastics underlain by hard limestone; the former is continuously eroded exposing the hard limestone, which bears the scar of the crown. The second landslide (1-6-4 in Figure 18 and 5 in Figure 19) has the same age, whereas the third one (S) is much younger from the other slides, few ten years old. 


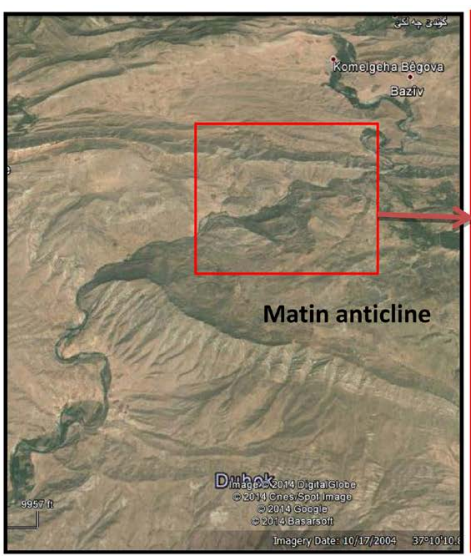

(A)

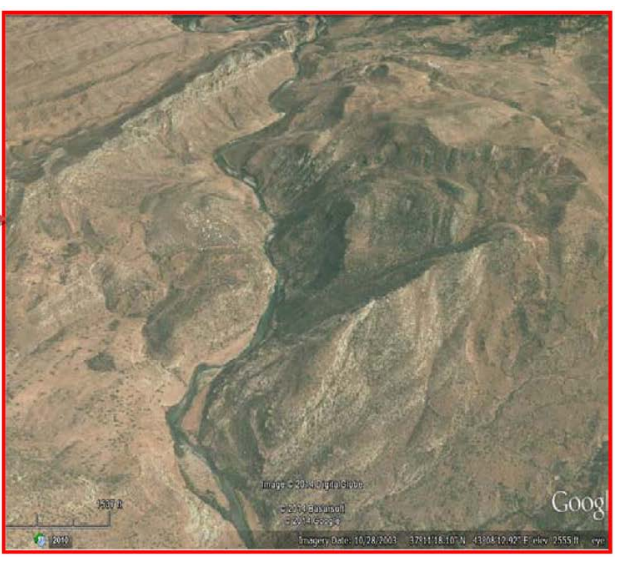

(B)

Figure 18. Google Earth image. (A)Fiesh Khabour River crossing Matin anticline and exhibiting intense mean- dering; (B) Details of a very large landslide.

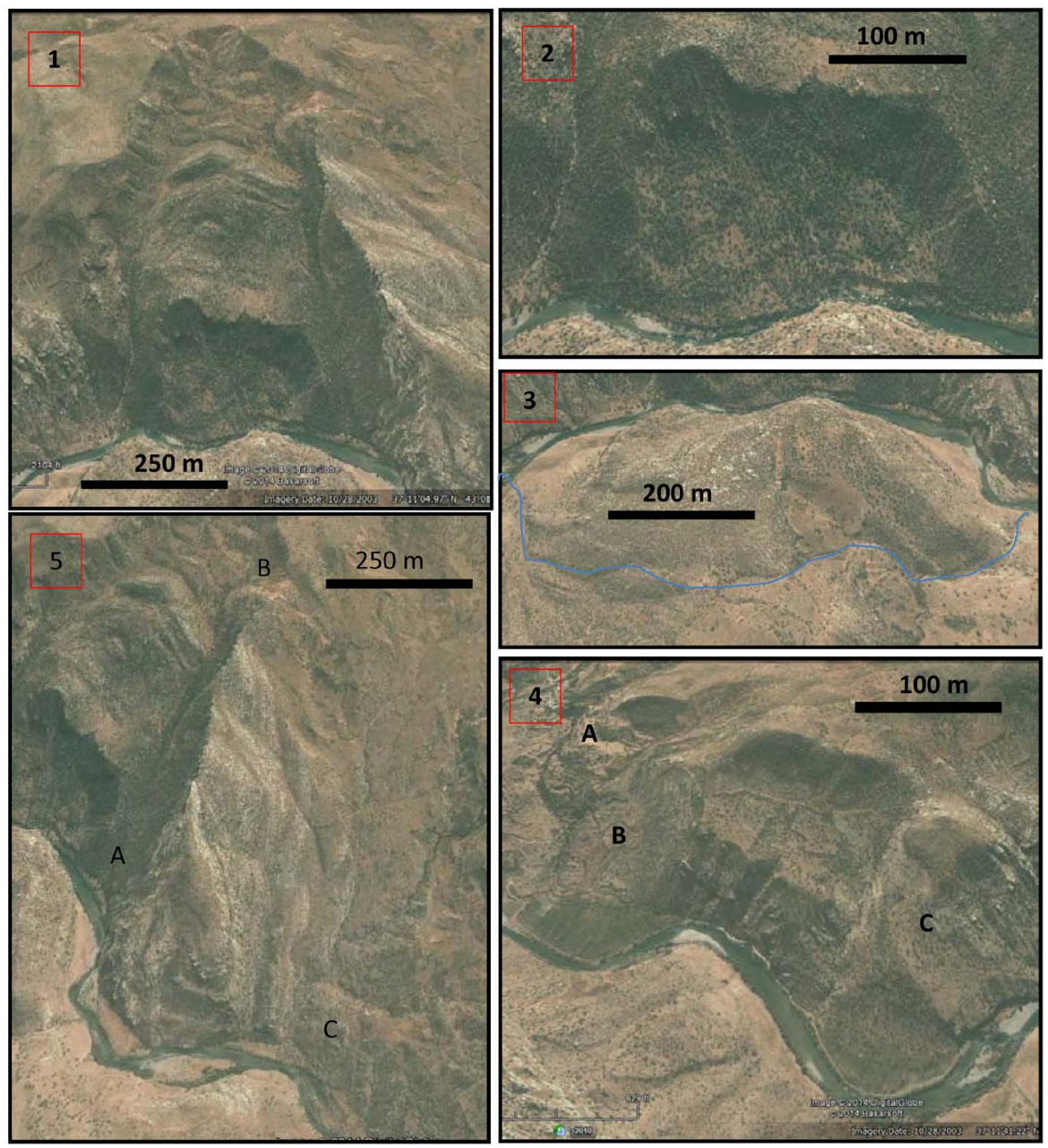

Figure 19. Google Earth image showing different details about the large landslide. 1) General view of the landslide facing the Fiesh Khabour River; 2) Details of the last landslide, note the scar, crown areas and the toe; 3) Trace of the ancient river course after the first landslide (marked by blue line); 4) Details of the left side of the large landslide; and 5) Details of the second landslide that had shifted the river course. 
Because the aforementioned landslide (Figure 18) is the most complex one within all other recognized landslides that have caused meandering of the rivers; therefore, it is discussed and shown in more details (Figure 19), as compared to other presented mass movements.

Figure 17; caption 1 show the details of the first landslide, although so old, but it is still active; as indicated from: 1) The toe area, which has shifted the river course again northwest wards (caption 2 in Figure 19). 2) The crown area, which indicates active erosion; due to unstable slope, and 3) The surroundings of the scar area (caption 2), which also shows active erosion; due to unstable slope. The involved area is about $0.089 \mathrm{Km}^{2}$.

Figure 19; caption 3 shows the details of the toe area of the first landslide, which consists of red clastics of the Gercus Formation. Note the hillocky shape of the existing slid mass, if it was not a slid mass, then it wouldn't had such hillocky shape, because it is higher in elevation than the normal beds, which underlie the cliff of the Pila Spi Formation (Figure 18, enlarged caption). The existing two valleys in opposite flowing direction with almost in one single alignment (marked by blue line in caption 3, Figure 19), indicate the location of the old course of the river; after it was shifted by the first landslide. If the two valleys wouldn't represent the old course, then the two valleys wouldn't flow in such form; parallel to the existing river, they should flow in perpendicular trend to the present river course. The involved area is about $0.13 \mathrm{Km}^{2}$.

Figure 19; caption 4 shows the right side of the first old landslide. Three younger landslides (A, B and C), as compared to the original first large old landslide. They all had shifted the river course northwest wards, and seem to be stable; hitherto. The crown areas in all of them are still visible. These three landslides have almost the same age, which can be estimated as few hundred years old, since there is no trace in the scar, crown and toe areas are still present. The three areas of A is $0.0037 \mathrm{Km}^{2}$, B is $0.0125 \mathrm{Km}^{2}$ and $\mathrm{C}$ is $0.0168 \mathrm{Km}^{2}$.

Figure 19; caption 5, shows a large limestone mass of the Khurmala Formation slid down the slope to the river causing shifting of the river course. This landslide although is very old, but still it is younger than the first old large landslide (1- 2-3 in Figure 18). The landslide has shifted the river course almost back to its original position after the shift caused by the first old large landslide. The slid mass is still not stable, as indicated from the presence of grooves and rills along the line A-B-C Figure 19, caption 5), it will slide down to the river after under cur erosion and increase of the water pore pressure in the clastic beds of the Kolosh Formation, which underlies the huge limestone mass of the Khurmala Formation. The involved area is about $0.098 \mathrm{Km}^{2}$.

\subsection{Rawandooz River}

The Rawandooz River is one of the largest streams in the northeastern part of Iraq; it merges to the Greater Zab River near Bekhme gorge. The river flows in very rugged topography with high relief differences; built-up by carbonates, shale, igneous and metamorphic rocks [26].

Figure 20(A) shows two meanders developed by two landslides within Jurassic rocks, which consists of carbonates and black shale beds [27]; the later form as lubricant for sliding, besides the weak resistance for wea-

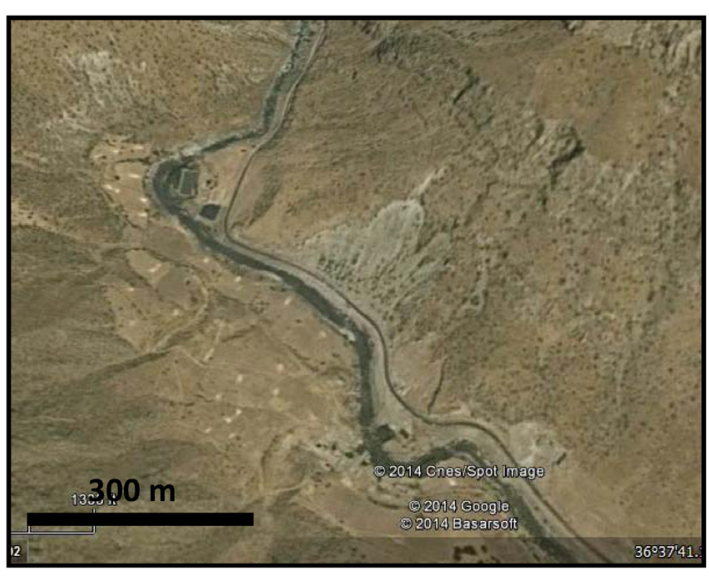

(A)

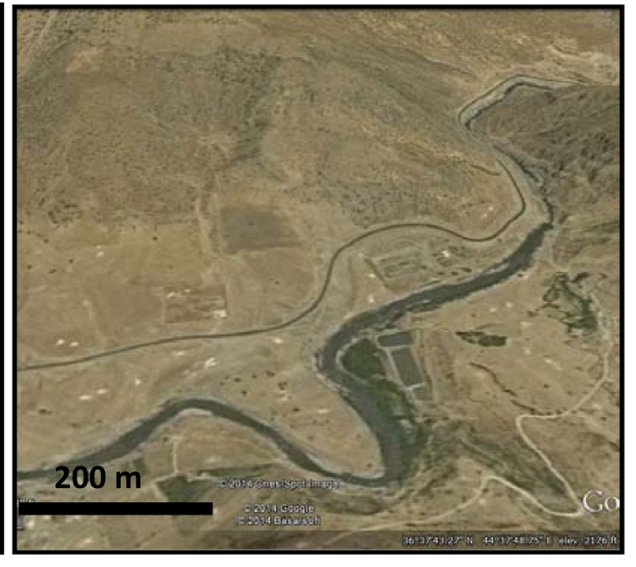

(B)

Figure 20. Google Earth images (facing north) of the Rawandooz River. (A) Exhibits two meanders due to landslides; (B) Exhibits a meander due to mud flow. Note that the scar and crown areas are still visible, but are dormant. 
thering and developing of mud flows. Figure 20(B) shows a horse shoe meander developed due to mud flow. The three meanders are very old; few hundred years old, this is indicated from: 1 ) The old river course; before shifting to form the three meanders is not visible, 2) The crown area in three cases, although still visible, but without any indication for recent activity, 3) The bulge in the toe area in the three cases is totally vanished, and 4) No any indication for the presence of any recent traces for active movement around the involved areas. However, downstream from the first meander (Figure 20(A)), clear indication can be recognized for very active erosion on the steep slope due to undercut of the meandering river. The coverage area of the left meander is about 0.0084 $\mathrm{Km}^{2}$, whereas that to the right is about $0.18 \mathrm{Km}^{2}$.

\subsection{Shamdinan River}

The Shamdinan River is a tributary of the Greater Zab River; it flows from Turkey inside Iraq in the extreme northern part. The river flows in very rugged topography with high relief differences, exhibiting steep and vertical very high cliffs, which consist of carbonates, shale beds and some igneous rocks [26].

Figure 21 shows the Shamdinan River exhibiting a wide meander developed due to a large landslide. The slid mass, which has length of about $2.5 \mathrm{Km}$ had shifted the course of the river southwest wards (the blue line in Figure 21). Consequently, the stream was blocked by the slid mass, and because the front of the slid mass is higher than its back side; therefore, the river succeeded to curve its new course in the back side of the slid mass forming the present course, exhibiting a wide meander.

Caption No. 1 in Figure 21 shows the details of a mud flow within the large slid mass. The marl and shale beds were flew down in downstream direction, also shifting the river course. Caption No. 2 in Figure 21 shows the details of the scar area of the large landslide area. Note that there is no continuation for the large flat iron; in extreme left side of the caption and it reappears again on the extreme right side. This means the whole mass slid down towards the stream during the large landslide. Caption No. 3 in Figure 21 shows the details of a mud flow that had occurred after the large landslide; also it shifted the river course in form of alluvial cone.

The age of the large landslide is very old; it is estimated as few hundred or even thousand years old, its coverage area is about $1.256 \mathrm{Km}^{2}$. The mud flow (Caption No. 1) is younger than the large landslide, because it has happened within the already slid mass and after the river returned to its original course; its coverage area is about $0.108 \mathrm{Km}^{2}$. The mud flow (Caption No. 3) is also younger than the large landslide, but it is difficult to estimate weather it is younger or otherwise than the mud flow in caption No. 1; its coverage area is about 0.152 $\mathrm{Km}^{2}$. The authors; however, believe that it is older than the other mud flow (Caption No. 1), this is attributed to the favorable conditions for triggering of a mass movement, which are more in this mud flow than the other (Caption No. 1). Moreover, the mud flow within the slid mass (Caption No. 1) has occurred after the river has returned to its original course, which means more time is needed for the river to curve within the already slid mass, which has height of about $276 \mathrm{~m}$; as measured from Google Earth image.

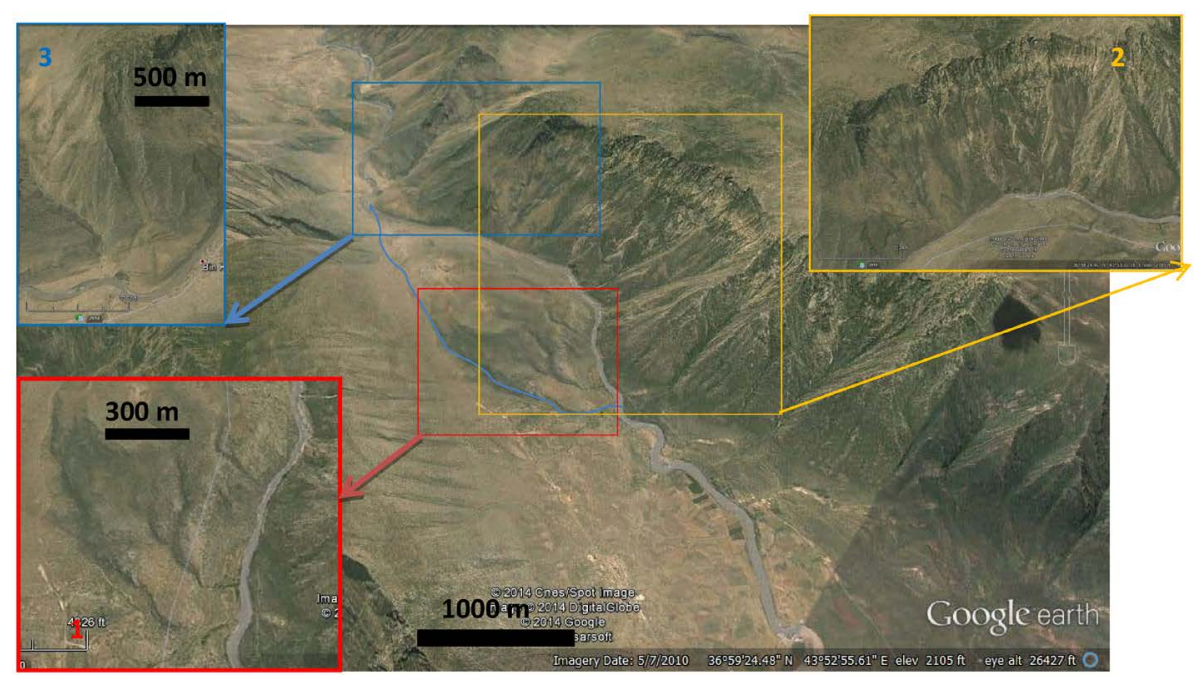

Figure 21. Google Earth image facing SW of the Shamdinan River. 


\section{Results}

The main rivers, streams and large valleys, in Iraq exhibit different types of meandering; as usual in all rivers, due to hydraulic mechanism and maturity of the river. Meanders; however, are developed due to different types of mass movements, which shift the course of the river and/or stream.

Hundreds of examples can be seen in Iraqi rivers, streams and large ephemeral valleys, in different parts of Iraq, especially in the north and northeastern parts, which are mountainous areas with decreasing relief towards the central part. The high relief difference with the presence of alternation of different rocks bearing different mechanical properties, besides increasing of pore water pressure; and occasionally man-made activities, all have played significant roles in development of different types of mass movements and triggering them, too.

\section{Discussion}

Rivers, streams and ephemeral valleys exhibit natural meandering in different cases, such as in mature parts of rivers Figure 3), hydraulic mechanism and overflows (Figure 3 and Figure 4). Meanders; however, also can be developed by shifting of the river course due to large alluvial fans (Figure 5) and due to mass movements.

In Iraq, the main types of mass movements are mud flows and landslides [10] [11]. Hundreds of events have occurred in all Iraqi rivers and streams forming different types of meanders, some of them are complex meanders Figure 10, Figure 11, Figure 16 and Figure 19), others are acute (Figure 7), horse shoe (Figure 8, Figure 14 and Figure 15), wide (Figure 9, Figure 12 and Figure 19) and multi meanders (Figure 16). Some of the meanders; however, exhibit different types at the same location (Figure 16 and Figure 19). Many meanders were selected from the rivers and streams to be representative examples for all the existing types of meanders caused by landslides and/or mud flows.

The majority of the mass movements are of landslide type occurred in alternation of carbonate rocks and claystone, shale and marl; those of mud flows are mainly in soft rocks, such as marl, claystone and shale. The main reasons for triggering of the mass movements are: Increase of pore water pressure; due to heavy rain storms, undercut erosion by rivers and/or streams, especially when the banks are very steep. Man-made activities, such as road cuts; however, are very rare; nevertheless some are very dangerous, like the one south of Derbendi Khan Dam (Figure 15). The sliding of the limestone mass, which has a volume of about 3,294,000 $\mathrm{m}^{3}$ will certainly cause a catastrophe, especially the surrounding areas area highly populated.

Some complex meandering of rivers occur; due to complex mass movements, which include landslide associated with mud flows. The slid masses have also suffered from mud flow (Figure16 and Figure 17). These usually happened when the slid mass blocks the course of the stream, especially when the gradient is high and the banks are very steep with high relief difference. The blocked stream, which is usually shifted towards the front of the slid mass, will return to its original course, after curving within the slid mass in its back side, because it is normally lower than the front side, which is usually located above the opposite stream bank, consequently has higher elevation (Figure16 and Figure 17).

The estimated exposure age determination [30] of the mass movements at each case depends on: 1) Presence or otherwise of the location and or traces of the crown, scar area and the toe, 2) Presence of terraces nearby to the meander (Figure 12), 3) Presence of vegetation within the involved area, 4) Presence or otherwise of the ancient river or stream course, 5) Presence of other type of mass movement; usually mud flow within the already slid mass, and 6) Presence of evidence (s) for active erosion in the meandering area. When more than one mass movement had occurred; developing more than one meander, then comparative age estimation is given, from the oldest to the youngest.

\section{Conclusions}

This study has the flowing conclusions:

- Almost all the Iraqi rivers, streams and perennial valleys have meanders developed by mass movements.

- Different types of meanders were developed, such as acute, horse shoe, wide and complex.

- Some meanders are associated with very critical and dangerous slopes, which will form catastrophic events when triggered down slopes.

- The main reasons for the mass movements are undercut erosion of the river or stream, increase of pore water pressure, and very rarely man-made activities. 
- The presence of rugged topography and high relief differences along the courses of the rivers, streams and valleys, with exposures of alternation of hard and soft rocks within the courses is favorable conditions for development of mass movements, consequently for shifting of the courses and development of meanders.

- Majority of the developed meanders are few hundred years old, and even more, although some are more recent, others are still active.

\section{References}

[1] Al-Ansari, N.A. (2013) Management of Water Resources in Iraq: Perspectives and Prognoses. Engineering, 5, 667-668. http://dx.doi.org/10.4236/eng.2013.58080

[2] ESCWA (Economic and Social Commission for Western Asia) (2013) Inventory of Shared Water Resources in Western Asia. Salim Dabbous Printing Co., Beirut, 626 p.

[3] Al-Ansari, N.A. and Knutsson, S. (2011) Toward Prudent Management of Water Resources in Iraq. Journal of Advanced Science and Engineering Research, 1, 53-67.

[4] Al-Ansari, N.A., Ali, A. and Knutsson, S. (2014) Present Conditions and Future Challenges of Water Resources Problems in Iraq. Accepted Journal of Water Resources and Protection.

[5] Immor, L. (2006) The Stages of River Development. Geoteach.com, Geoloar (Internet Data). www.sswm.info/.../IMMOR\%202006\%20Classification\%20Rivers.pdf

[6] Varnes, D.J. (1976) Landslides, Causes and Effects. Bulletin IAEG No. 14, 205-214.

[7] Varnes, D.G., Harold, T.R. and Lang, T. (1978) Landslide Analysis and Control. National Academy of Sciences, Washington DC.

[8] Sissakian, V.K. (1998) Mass Movements. Journal of Geological Arabic Development, No. 1-2.

[9] Sissakian, V.K. (1998) Mass Movements, Examples from Iraq. Proceedings of the 6th Jordanian Geological Congress, Amman, 1988, 211-219.

[10] Terzaghi, K. (1967) From Theory to Practice in Soil Mechanics. John Wiley and Sons, New York.

[11] Terzaghi, K., Peck, R.B. and Mesri, G. (1996) Soil Mechanics in Engineering Practice. 3rd Edition, Wiley-Interscience.

[12] Monroe, W. (2005) The Changing Earth: Exploring Geology and Evolution. Thomson Brooks/Cole.

[13] Sissakian, V.K. and Fouad, S.F. (1999) Morphotectonics of the Tigris River along Khanoogah Anticline, Central Part of Iraq.

[14] Karim, K.H., Hamasur, G.A. and Tofiq, S.M. (2000) Qara-Chatan Rockslide in Pira-Magroon Anticline, Northeastern Iraq. Journal of Zankoy Sulaimani, Part A, 3, 33- 47.

[15] Sissakian, V.K., Fouad, S.F. and Salih, H.A. (2003) The Landslides of Khanooqa Area, Central Part of Iraq. Iraqi Journal of Earth Sciences, 3, 1-7.

[16] Sissakian, V.K., Fouad, S.F. and Al-Musawi, H.A. (2005) The Influence of the Unstable Slopes on the Stability of Makhul Dam, Central Iraq. Iraqi Bulletin of Geological Mining, 2, 31-44.

[17] Sissakian, V.K. and Abdul-Jabbar, M.F. (2010) Morphometry and Genesis of the Main Transversal Gorges in North and Northeast Iraq. Iraqi Bulletin of Geological Mining, 6, 95-120.

[18] Hamsur, Gh.A. (2013) Slope Stability Assessment within and around the Reservoir of the Proposed Basara Dam, Sulaimaniyah, NE Iraq. Iraqi Bulletin of Geological Mining, 9, 51-66.

[19] Nelson, S.A. (2014) Mass Movements. Physical Geology. Tulane University. Internet Data. www.britannica.com/EBchecked/topic/368257

[20] Al-Ansari, N.A., Sayfy, A., Ovanessian, A.A. and Al-Sinawi, G.T. (1986) Water Quality of the River Tigris North of Baghdad Using Multivariate Analysis. Water Research, 5, 148-172.

[21] Al-Ansari, N.A., Sayfy, A., Al-Sinawi, G.T. and Ovanessian, A.A. (1986) Evaluation of the Water Quality for the Lower Reaches of River Tigris Using Multivariate Analysis. Water Research, 5, 173-187.

[22] Al-Ansari, N.A., Salman, H.H. and Al-Sinawi, G.T. (1987) Periodicity of Selected Water Quality Parameters for the Tigris Water at Baghdad. Water Research, 6, 11-17.

[23] Al-Ansari, N.A., Assaid, H.I. and Salim, V.N. (1981) Water Resources in Iraq. Journal of the Geological Society, 15, 35-42.

[24] Al-Ansari, N.A., Assad, N., Walling, D.E. and Hussan. S.A. (1988) The Suspended Sediment Discharge of the River Euphrates at Haditha, Iraq: An Assessment of the Potential for Establishing Sediment Rating Curves. Geografiska Annaler, Series A, Physical Geography, 70, 203-213.

[25] Al-Kadhimi, J.A.M., Sissakian, V.K., Fattah, A.S. and Deikran, D.B. (1996) Tectonic Map of Iraq, Scale 1: $1000,000$. 
2nd Edition, Geosurv, Baghdad.

[26] Sissakian, V.K. and Fouad, S.F. (2012) Geological Map of Iraq, Scale 1: 1000,000. 4th Edition, Geosurv, Baghdad.

[27] Sissakian, V.K. and Fouad, S.F. (2014) The Geology of Erbil and Mahabad Quadrangles, Scale 1: 250,000. 2nd Edition, Geosurv, Baghdad.

[28] Sissakian, V.K. and Fouad, S.F. (2014) The Geology of Kirkuk Quadrangle, Scale 1: 250,000. 2nd Edition, Geosurv, Baghdad.

[29] Sissakian, V.K. and Fouad, S.F. (2014) The Geology of Sulaimaniyah Quadrangle, Scale 1: 250 000. 2nd Edition, Geosurv, Baghdad.

[30] Keller, E.A. and Pinter, N. (2002) Active Tectonics, Earthquakes, Uplift and Landscape. 2nd Edition, Prentice Hall, Upper Saddle River, 362 p. 
Scientific Research Publishing (SCIRP) is one of the largest Open Access journal publishers. It is currently publishing more than 200 open access, online, peer-reviewed journals covering a wide range of academic disciplines. SCIRP serves the worldwide academic communities and contributes to the progress and application of science with its publication.

Other selected journals from SCIRP are listed as below. Submit your manuscript to us via either submit@scirp.org or Online Submission Portal.
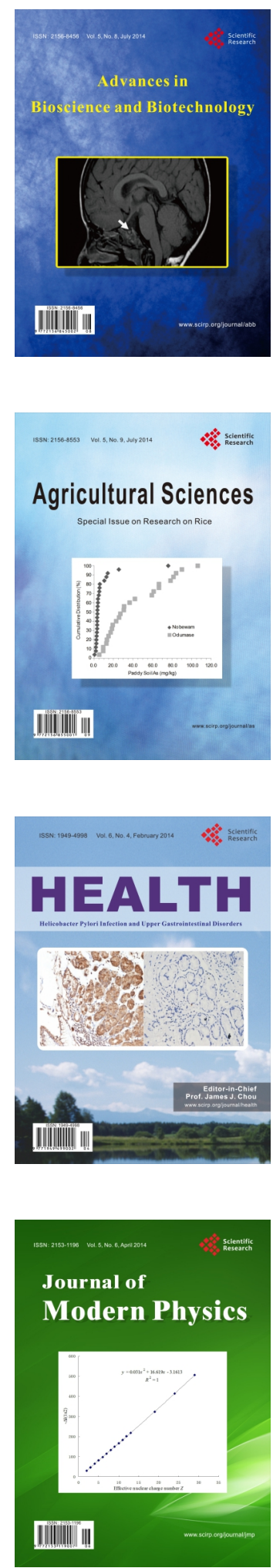
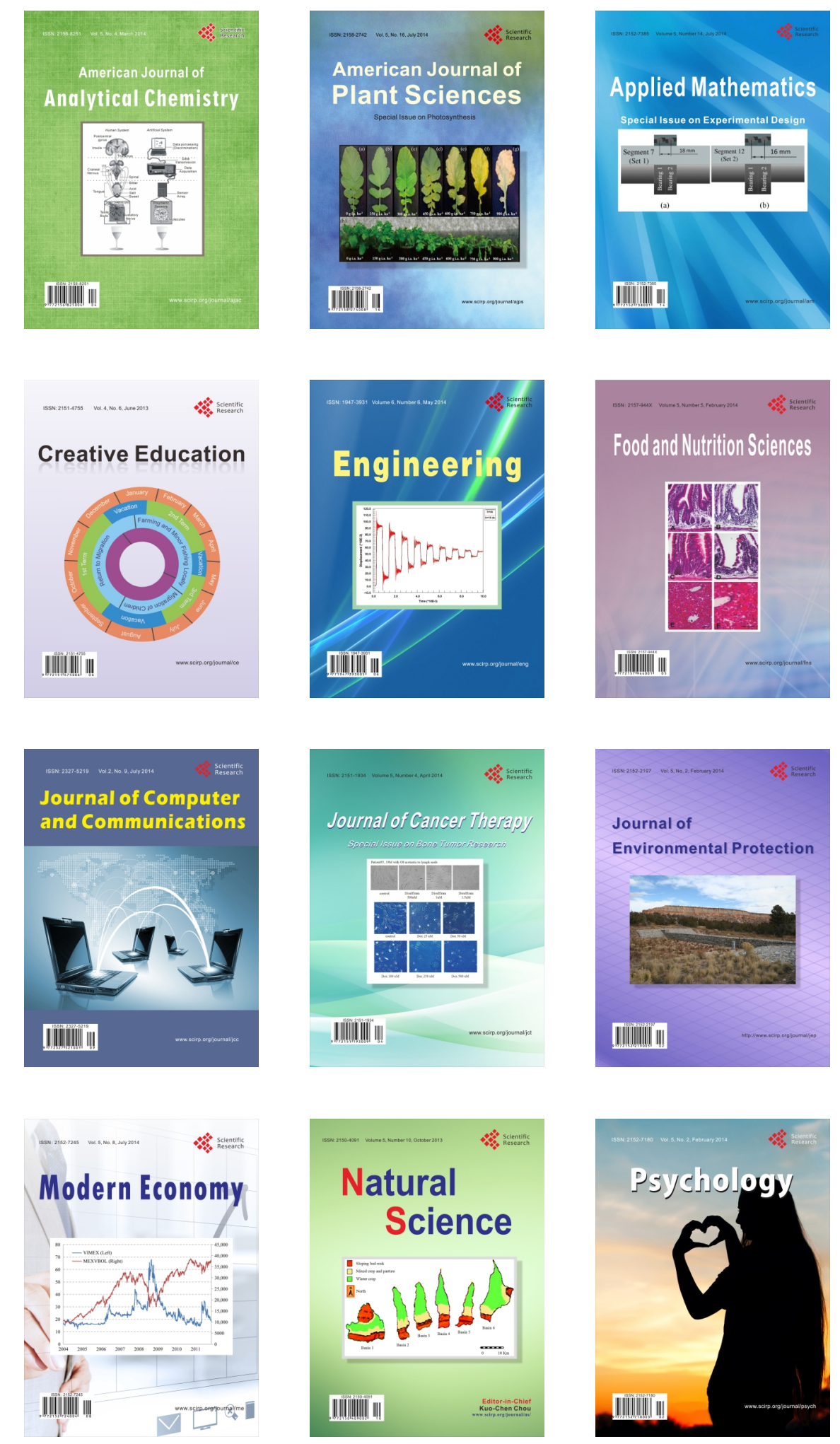